This is the final peer-reviewed accepted manuscript of:

Gunaalan K.; Fabbri E.; Capolupo M.: The hidden threat of plastic leachates: A critical review on their impacts on aquatic organisms. WATER RESEARCH 184. 0043-1354

DOI: 10.1016/j.watres.2020.116170

The final published version is available online at:

http://dx.doi.org/10.1016/i.watres.2020.116170

Rights / License:

The terms and conditions for the reuse of this version of the manuscript are specified in the publishing policy. For all terms of use and more information see the publisher's website.

This item was downloaded from IRIS Università di Bologna (https://cris.unibo.it/)

When citing, please refer to the published version. 


\title{
The hidden threat of plastic leachates: A critical review on their impacts on aquatic organisms
}

\author{
Kuddithamby Gunaalan $^{\mathrm{a}}$, Elena Fabbri ${ }^{\mathrm{a}, \mathrm{b}, *}$, Marco Capolupo $^{\mathrm{b}}$ \\ ${ }^{a}$ Interdepartment Centre for Environmental Science Research, University of Bologna, Ravenna, Italy \\ ${ }^{\mathrm{b}}$ Department of Biological, Geological and Environmental Sciences (BIGEA), University of Bologna, Ravenna, Italy
}

\begin{abstract}
A B S T R A C T
Plastic products are made from the essential polymer mixed with a complex blend of substances including catalyst remnants, polymerization solvents, and a wide range of other additives deliberately added to enhance the desirable characteristics of the final product. Additives include bisphenols, phthalates, flame retardants, and further emerging and legacy contaminants. With a few exceptions, additives are not chemically bound to the polymer, and potentially migrate within the material reaching its surface, then possibly leach out to the environment. Leachates are mixtures of additives, some of which belong to the list of emerging contaminants, i.e. substances that show the potential to pose risks to the environment and human health, while are not yet regulated. The review discusses the state of the art and gaps concerning the hidden threat of plastic leachates. The focus is on reports addressing the biological impacts of plastic leachates as a whole mixture. Degradation of plastics, including the weathering-driven fragmentation, and the release of additives, are analysed together with the techniques currently employed for chemically screening leachates. Because marine plastic litter is a major concern, the review mainly focuses on the effects of plastic leachates on marine flora and fauna. Moreover, it also addresses impacts on freshwater organisms. Finally, research needs and perspectives are examined, to promote better focused investigations, that may support developing different plastic materials and new regulations.
\end{abstract}

\author{
Keywords \\ Plastic additives \\ Leachate preparation \\ Chemical screening \\ Aquatic organisms \\ Ecotoxicity
}

\section{Introduction}

Quantities of solid waste are increasing globally. Plastics are a major fraction of this waste, and the foremost category of litter reported in the ocean (Napper and Thompson, 2019). It is estimated to be between $50 \%$ and $90 \%$ (Agamuthu et al., 2019) and sometimes up to $95 \%$ of the total waste found on shorelines, sea surface and seafloor (Galgani et al., 2015). Most plastic materials are made of organic polymers synthetically produced using feedstocks deriving from natural gas processing or crude oil refining. Generally, they are the ultimate product of convenience because of their properties ranging from lightweight to high strength and durability; thus, they are ubiquitous, versatile and play several roles for societal benefits (Andrady and Neal, 2009). On the other hand, the increasing occurrence of plastic in the environment has become one of the most concerning issues among scientists and policy makers. The rate of plastic production has exponentially risen worldwide during the past decades, passing from 1.5 million tons in 1951 to around 335 million tons in 2016 (PlasticsEurope, 2017). As a consequence of increasing plastic discharge, nearly eight million tons of plastics are estimated to flow into the oceans every year from either land- or sea-based sources (Gallo et al., 2018).

\footnotetext{
* Corresponding author.

E-mail address: elena.fabbri@unibo.it (E. Fabbri)
}

Plastics are classifiable based on their chemical structure, polarity and application. Globally, polyethylene (PE), polypropylene (PP), polystyrene (PS), polyethylene terephthalate (PET), and polyvinyl chloride (PVC) are the classes of synthetic polymers most frequently used in highest-volume industrial applications, and are therefore widely detected and worldwide distributed in marine and coastal environments (Hidalgo-Ruz et al., 2012). Physicochemical forces such as wave action, photodegradation and other weathering processes lead to the progressive fragmentation of oceanic plastics, which might thus be categorised into macroplastics ( $>20 \mathrm{~mm}$ diameter), mesoplastics $(5-20 \mathrm{~mm}$ diameter), microplastics (MPs, $<5 \mathrm{~mm}$ diameter) down to nanoplastics (NPs, from $1 \mu \mathrm{m}$ to $1 \mathrm{~nm}$ ) (Franzellitti et al, 2019; GESAMP, 2016). To these, native plastic items directly commercialized as microor nano-sized particles for industrial purposes (known as primary micro/ nanoplastics) must be added (Ribeiro et al., 2019).

Macro/mesoplastics seem to prevail in tonnage, while MPs are the most numerically abundant. Sediment is generally considered to be a final sink for MPs. Items denser than seawater will naturally sink and end up in sediments. However, the density of MPs originally lighter than seawater may increase under the effect of biofilm formation, ingestion/egestion by animals, or aggregation with marine organisms (Ioakeimidis et al., 2019). A recent study in the Beibu Gulf (Xue et al., 2020) concluded that most MPs are hidden in deep sediments (from 5 to $60 \mathrm{~cm}$ ), with amounts five times higher than those in surface sediments. MP pollution within water columns is likely to be underesti- 
mated, because $80 \%$ of the field studies sampled MPs with size greater than $300 \mu \mathrm{m}$, thus excluding particles of smaller size (Lindeque et al., 2020).

MPs are mistaken for natural food by a wide range of marine organisms (Franzellitti et al. 2019, GESAMP, 2016; UNEP, 2016). Filter- and deposit-feeders may accidentally ingest MPs, while higher trophic levels usually accumulate plastics indirectly via biomagnification (GESAMP, 2016). Most studies on MP have been addressed to the potential effects of their physical presence and distribution along the food chain (Galloway et al., 2017; GESAMP, 2016; UNEP, 2016). The most obvious impact of these items is physical damage or blockage of the digestive tract, together with a false sense of satiation, which reduces appetite and food intake. Plastics in the nanometre scale are ingested or trapped by the gill filaments and may enter the blood after migrating across the surfaces (Ryan, 2019). Furthermore, plastics can carry waterborne pollutants, mainly hydrophobic compounds, which may affect organisms when released after ingestion, and/or biomagnify along the marine trophic chain (Galloway and Lewis, 2016; Gonzàlez-Soto et al., 2019).

The fragmentation and degradation of plastics may facilitate the release of additive chemicals, most of which are not covalently bound to the polymers, and are thus prone to be released into the environment (Kwan and Takada, 2016; Teuten et al., 2009). A prominent group of additives consist of metals ranked high with regard to human health hazards, as aluminium, chromium, cobalt, nickel, tin, and zinc (e.g. Capolupo et al., 2020). Among organics, well known additives are BPA, phthalates, and brominated flame retardants (BFRs), proven over many years to have harmful effects on living organisms (e.g. Baršienè et al., 2006; Bollmann et al., 2012; Canesi and Fabbri, 2015; Balbi et al., 2016; Wang et al., 2020).

The European Chemical Association characterised over 400 substances used as plastic additives (ECHA, 2018), many of which are regulated under European and North American legislation to limit their possible impacts on human health. As shown in Table 1, phthalates esters and some polybrominated diphenyl ethers (PBDEs) and hexabromocyclododecane (HBCDs) congeners used as BFRs are currently subjected to ban, restrictions, or assigned to particular risk assessment procedures under the EU's REACH Regulation. Particular attention has also been addressed to the BPA addiction to food contact material (FCM), for which a migration limit of $0.05 \mathrm{mg} / \mathrm{kg}$ of food has been defined. In addition, EU Regulation EC/10/2011 recommends the use of plastic-made FCM specifically designed to prevent the additive migration into food. Similar guidelines have been introduced by the GMC resolution $\mathrm{N}^{\circ} 39 / 19$ of the South-American Trading Bloc (MERCOSUR), which sets compositional and other limits or usage restrictions for nearly 1150 substances (Tovar, 2019).

Some of the substances used as plastic additives, such as HBCDs, PBDEs, nonylphenol and diethylhexyl phthalate (DEHP) have been included, as priority substances, under the Water Framework Directive (2000/60/EC). Environmental Quality Standards (EQSs) for surface waters have also been introduced in the EU for these substances (2008/ 105/EC; 2013/39/EU) (Table 1). However, no environmental safety thresholds have yet been defined for many other classes of additives, including BPA, known for its ubiquity in surface waters and endocrine disrupting effects on aquatic organisms (reviewed by Canesi and Fabbri, 2015), and several organophosphate esters (OPEs) used as flame retardants. Migration tests were recently performed on virgin and/or beach-collected MPs. These highlighted the presence of a suite of chemical additives in the leachates, including legacy pollutants, as metals, organic substances as benzothiazole, acetophenone and phthalide and many other substances for which the lack of pertinent environmental fate and ecotoxicological data prevent a proper evaluation of associated risks (Capolupo et al., 2020; Schiavo et al., 2020; Tetu et al., 2019). The additive leaching by plastics discharged in the environment may thus expose wild animal species to complex chemical mixtures containing not only components regulated under the current environ- mental legislation but also a number of contaminants of emerging concern (CECs). The latter are chemicals showing the potential to pose risks to the environment which are not yet subjected to environmental risk assessments, regular monitoring plans or legislative standards aimed at preventing their impacts on ecosystems.

A recent paradigm shift in plastic additive toxicology is thus related to the need for testing the adverse effects of the chemical extract or leachate from a given plastic material rather than single plastic additives (Groh et al., 2019). Although studies addressing the release of additives from plastics have started decades ago (i.e. Berens, 1997), threats to living organisms and environmental risks associated to the mixture of additives leached from plastic items gained attention more recently; papers addressing this topic have appeared in the literature only few years ago.

The aim of the review is to bring on the stage the hidden threat of plastic leachates providing information on the state of art and mapping the gaps in our knowledge. The focus is on reports specifically addressed to plastic additive leachates as a whole. The majority of available data have been published in the latest three years, and those where the leachate content was analytically determined are highlighted. Since marine plastic litter is a major concern, the review refers mainly to the effects of leachates on marine microorganisms, plants, invertebrates, and vertebrates. However, also impacts on freshwater organisms are addressed. Finally, research gaps and perspectives are examined, to promote better focused investigations, that may support design of different plastic materials and/or definition of new regulations.

\section{Type, fate and impacts of plastic additives}

\subsection{Additive classification}

Plastics are made of a core polymer complexed with a set of chemicals differing for origin (natural or synthetic), structure, functions and source. The chemicals associated with plastics can be classified in four categories: chemicals intentionally added during the production process, unintentional products of the manufacturing processes, by-products of the plastic waste recycling, and hydrophobic compounds adsorbed from the surrounding environment (Gallo et al., 2018; Mayer et al., 2000). Among them, intentionally added chemicals - henceforth addressed to as additives - have been recently cited as a potential hidden threat to the ecosystem (Gallo et al., 2018; Franzellitti et al., 2019). Additives are used to modify the resin features by either enhancing the desirable characteristics of the plastic product or lessen the unwanted properties (Murphy, 2001). According to a recent classification, additives can be categorised based on their functional and structural components into four major classes: functional additives, colorants, fillers and reinforcements (Hansen et al., 2013). Functional additives include substances designed to modify the physicochemical properties of polymers (from plasticizers to foaming agents). Colorants include pigments and azocolorants widely used to treat textile products; fillers include substances as clay, talc or carbonates aimed at improving polymer coating properties, while stabilizers include synthetic fibers used to increase the products mechanical resistance (Hansen et al., 2013).

Most of the additives represent a few percentages by weight of the polymer (e.g. biocides, odorants, antistatics and antiozonants may represent up to $1-2 \%$; colorants from 1 to $4 \%$ ) while others are used at a much higher weight: thermal stabilizers up to $8 \%$; flame retardants from 10 to $20 \%$; plasticisers from 10 to $70 \%$; fillers up to $50 \%$ (Andrady and Rajapakse, 2019).

Over the past decades, a significant amount of experimental studies have been focused on the effects of single additives on aquatic organisms. Based on their widespread presence in natural environment and well-known endocrine disrupting activity, BPA and phthalates, used as plasticizers and to increase the polymer flexibility, are among the most commonly studied additives (ECHA, 2018; UNEP, 2016). As reported in Table 2, many organisms among fish, crustaceans and mol- 
Table 1

Legislative interventions undertaken at international level to mitigate the impacts of plastic additives.

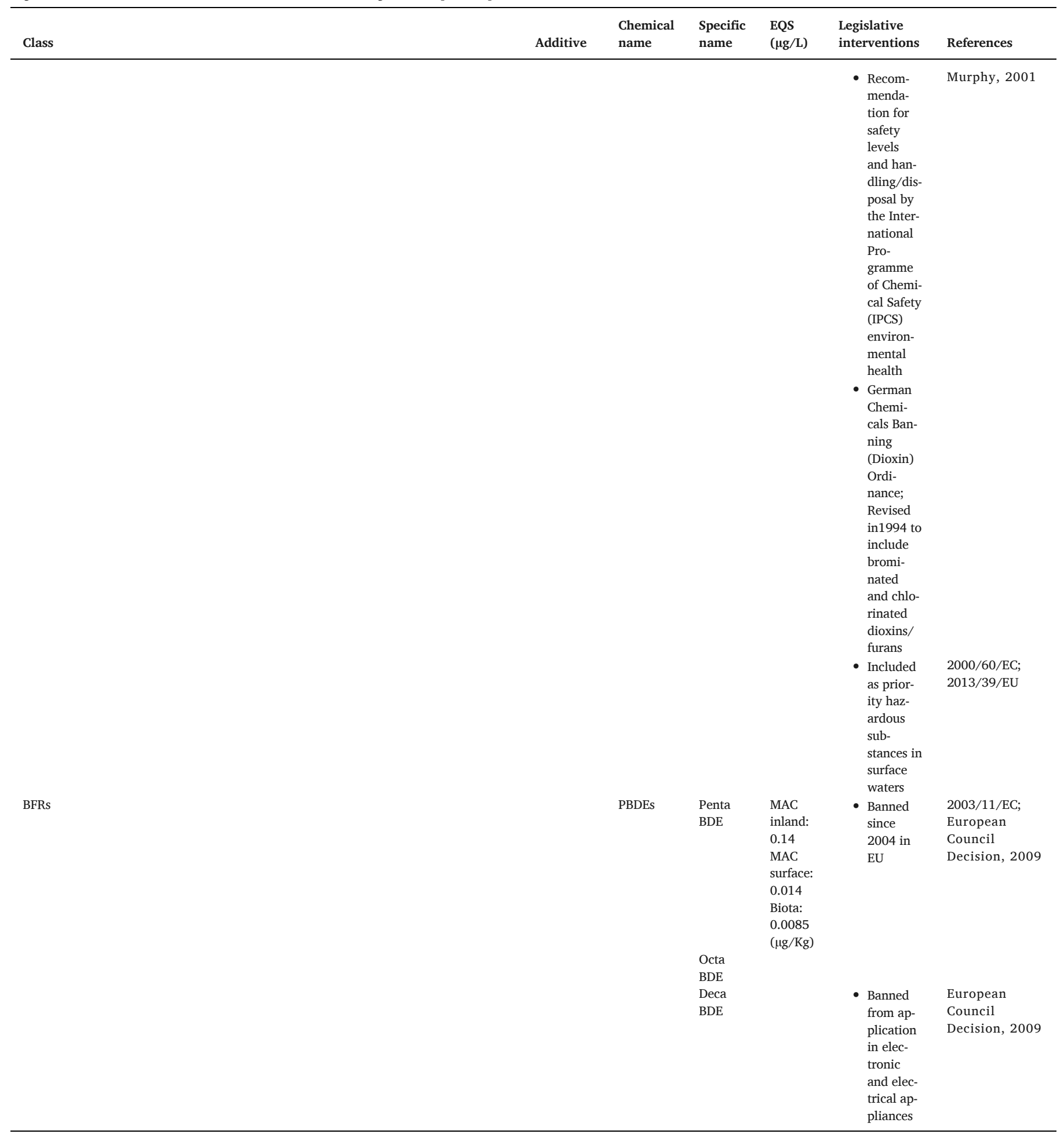


Tetra to

Hepta

BDE
- Elimination from

Annex A

of the

Stock-

holm

Conven-

tion on

persistent

organic

pollutant

(POP)
Stockholm

Convention,

2016 
Table 1 (Continued)

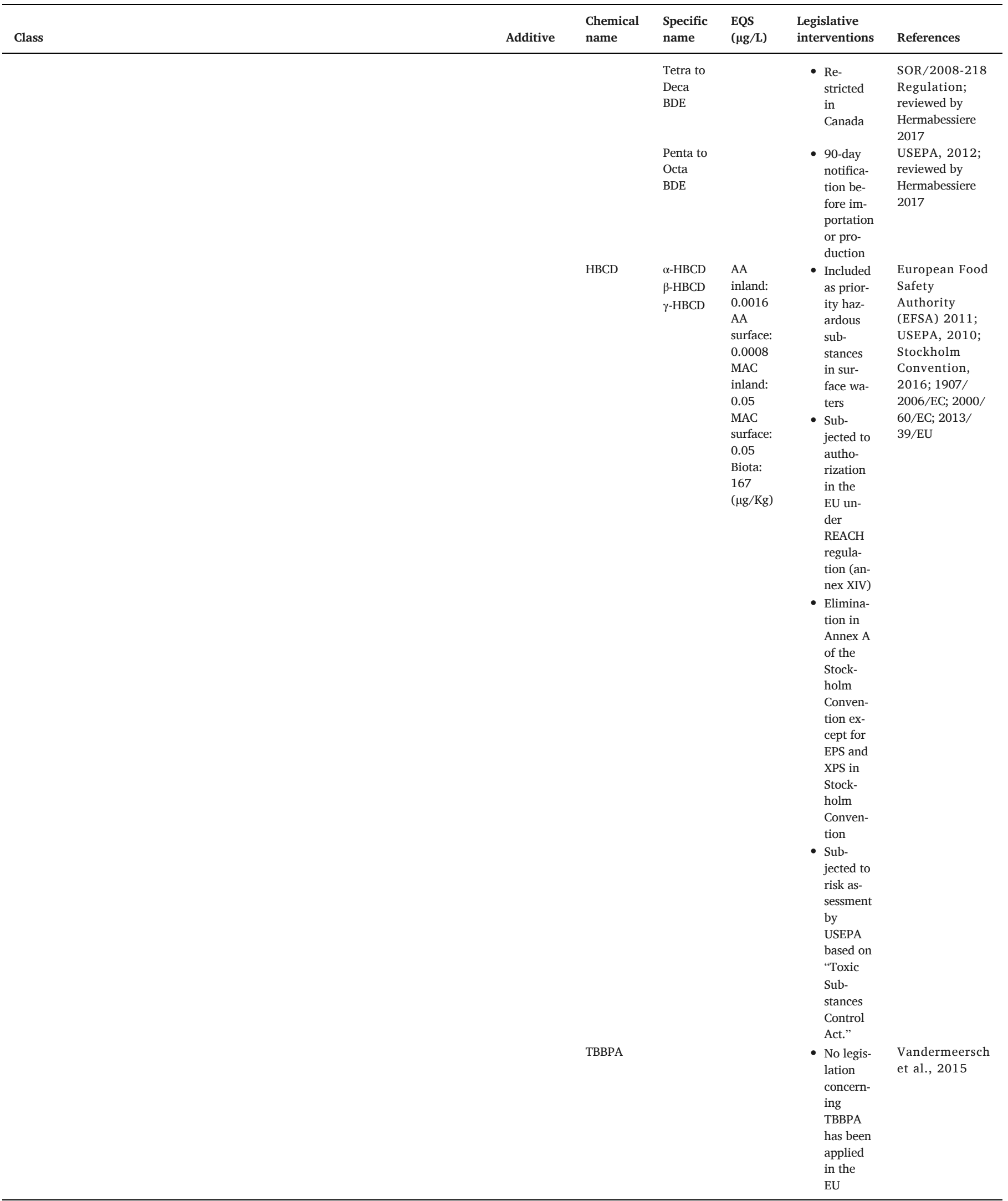




\begin{tabular}{|c|c|c|c|}
\hline Plasticizer & phthalates DINP & $\begin{array}{l}\text { - No war- } \\
\text { rant un- } \\
\text { der EU's } \\
\text { Classifi- } \\
\text { cation } \\
\text { and La- } \\
\text { belling } \\
\text { and } \\
\text { Packag- } \\
\text { ing } \\
\text { (CLP) }\end{array}$ & ECHA, 2018 \\
\hline
\end{tabular}

Table 1 (Continued)

\begin{tabular}{|c|c|c|c|c|c|c|}
\hline Class & Additive & $\begin{array}{l}\text { Chemical } \\
\text { name }\end{array}$ & $\begin{array}{l}\text { Specific } \\
\text { name }\end{array}$ & $\begin{array}{l}\text { EQS } \\
(\mu \mathrm{g} / \mathrm{L})\end{array}$ & $\begin{array}{l}\text { Legislative } \\
\text { interventions }\end{array}$ & References \\
\hline & \multirow{3}{*}{ Phenols } & \multicolumn{2}{|c|}{$\begin{array}{l}\text { DEHP, BBP, DBP, } \\
\text { DIBP }\end{array}$} & $\begin{array}{l}\text { AA } \\
\text { (DEHP) } \\
\text { inland: } \\
0.0016 \\
\text { AA } \\
\text { (DEHP) } \\
\text { surface: } \\
0.0008\end{array}$ & $\begin{array}{l}\text { - Use re- } \\
\text { striction } \\
\text { in indus- } \\
\text { trial/ } \\
\text { medical } \\
\text { products } \\
\text { - Included } \\
\text { as prior- } \\
\text { ity haz- } \\
\text { ardous } \\
\text { sub- } \\
\text { stances in } \\
\text { surface } \\
\text { waters }\end{array}$ & $\begin{array}{l}\text { 2015/863/EU; } \\
\text { 2000/60/EC; } \\
2013 / 39 / E U\end{array}$ \\
\hline & & BPA & & & $\begin{array}{l}\text { - limits for } \\
\text { leaching } \\
\text { in FCM } \\
\text { defined at } \\
\text { EU level }\end{array}$ & $\begin{array}{l}\text { ECR, 2011; } \\
\text { 2018/213/EU }\end{array}$ \\
\hline & & \multicolumn{2}{|c|}{ 4-nonylphenol } & $\begin{array}{l}\text { AA } \\
\text { inland: } \\
0.3 \text { AA } \\
\text { surface: } \\
0.3 \\
\text { MAC } \\
\text { inland: } \\
2 \text { MAC } \\
\text { surface: } \\
2\end{array}$ & $\begin{array}{l}\text { - Included } \\
\text { as prior- } \\
\text { ity haz- } \\
\text { ardous } \\
\text { sub- } \\
\text { stances in } \\
\text { surface } \\
\text { waters }\end{array}$ & $\begin{array}{l}\text { 2000/60/EC; } \\
\text { 2013/39/EU }\end{array}$ \\
\hline
\end{tabular}

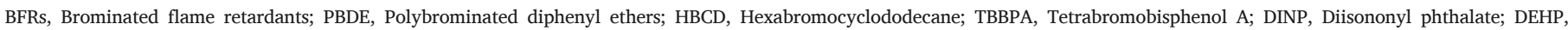

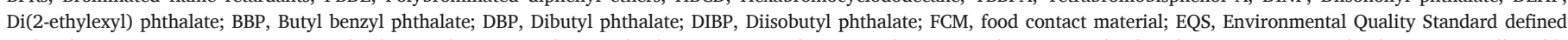

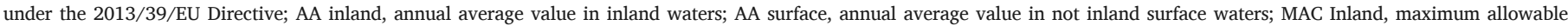
concentration in inland waters; MAC surface, maximum allowable concentration in not inland surface waters.

luscs were found to be affected by these compounds, with effect spanning from estrogenic (BPA) or antiestrogenic (phthalates) pathways, lysosomal disorders, oxidative stress, up to alterations of the organisms' behaviour or community structure. However, recent evidence confirms that these substances represent a minimal part of the chemicals leached by plastics in aquatic systems (Capolupo et al., 2020; Tetu et al., 2019). Therefore, the environmental impacts of additives should be assessed based on the whole mixture of substances leached out from the polymeric core, which might finally lead to cumulative effects on the exposed biota.

\subsection{Potential additive leaching in the marine environment}

The chemical hazard of plastics in the marine environment is triple, due to i) POPs released from the plastic surface, ii) additives leaching out of the plastics and iii) chemicals produced by the degradation of the plastic polymer. The pathways involved in plastics environmental degradation depend on the polymer type and may consist in the succession of abiotic and/or biotic processes. As shown in Fig. 1, plastic materials showing a carbon-carbon backbone, as PP, PE, PS and PVC, are mostly susceptible to photo- and thermo-oxidation, while hy- drolytic processes play a significant role in the degradation of polymers containing heteroatoms, as polyurethane (PU) and PET (Gewert et al., 2015). Overall, these processes lead to the progressive depolymerization of plastics, and are associated to release of carbonyl groups, hydroperoxides, alcohols and hydrochloric acid, among others. The photothermally or hydrolytically induced fragmentation of plastic litter generally precedes biodegradation, which is mediated by either cellular or extracellular enzymes produced by biofilm-forming microbes (Gewert et al., 2015).

Weathering forces are also known to stimulate the leaching of additive chemicals along with the plastic fragmentation from macro- to micro-sized items (Bejgarn et al., 2015; Luo et al., 2019) (Fig. 2). As established in the past ten years, beached and floating MPs show a wide variety of complexed additives. In a large survey focusing on expanded polystyrene (EPS) fragments from the Asia-Pacific coastal region, Jang et al. (2017) found concentrations of HBCDs in the range of $0.98-14,500 \mathrm{ng} / \mathrm{g}$. The highest levels were recorded in samples from Alaska (USA, $3350 \pm 5860 \mathrm{ng} / \mathrm{g}$ ), followed by Peru, Canada and California (USA). Similarly, PBDEs levels in PP and PE MPs from open ocean, remote and urban beaches sampled at global scale showed values in the range of $0.3-9900 \mathrm{ng} / \mathrm{g}$ (Hirai et al., 2011; Taniguchi 
Table 2

Literature information regarding the physiological effects of two of the most representative classes of endocrine disrupting plastic additives, i.e. phthalates and BPA on aquatic organisms

\begin{tabular}{|c|c|c|c|c|}
\hline $\begin{array}{l}\text { Class of } \\
\text { additive }\end{array}$ & $\begin{array}{l}\text { Specific } \\
\text { name }\end{array}$ & Species & Impacts & References \\
\hline \multirow[t]{6}{*}{ Phthalates } & \multirow[t]{3}{*}{ DEHP } & $\begin{array}{l}\text { Mytilus } \\
\text { galloprovincialis }\end{array}$ & $\begin{array}{l}\text { Increase in } \\
\text { catalase and } \\
\text { acyl-CoA oxidase } \\
\text { activity; } \\
\text { inhibition of Mn- } \\
\text { superoxide } \\
\text { dismutase }\end{array}$ & $\begin{array}{l}\text { Orbea et al., } \\
2002\end{array}$ \\
\hline & & Oryzias latipes & $\begin{array}{l}\text { Reduction in } \\
\text { vitellogenin and } \\
\% \text { of mature } \\
\text { oocytes in } \\
\text { females; anti- } \\
\text { estrogenic } \\
\text { activity }\end{array}$ & $\begin{array}{l}\text { Kim et al., } \\
2002\end{array}$ \\
\hline & & Cyprinus carpio & $\begin{array}{l}\text { High } \\
\text { bioconcentration; } \\
\text { changes in } \\
\text { enzymes } \\
\text { activities on the } \\
\text { synthesis of } \\
\text { endogenous } \\
\text { steroid hormones } \\
\text { and their } \\
\text { metabolism }\end{array}$ & $\begin{array}{l}\text { Staples et } \\
\text { al., } \\
\text { 1997; Thibaut } \\
\text { \& Porte } 2004\end{array}$ \\
\hline & DAP & Mytilus edulis & $\begin{array}{l}\text { Increase in } \\
\text { micronuclei } \\
\text { frequency; } \\
\text { fragmented } \\
\text { apoptotic cells in } \\
\text { gills }\end{array}$ & $\begin{array}{l}\text { Barsiene et } \\
\text { al., } 2006\end{array}$ \\
\hline & DBP & zoomacrobenthos & $\begin{array}{l}\text { changes in } \\
\text { community } \\
\text { structure \& } \\
\text { colonization } \\
\text { profiles }\end{array}$ & $\begin{array}{l}\text { Tagatz et al., } \\
1986\end{array}$ \\
\hline & BBP & $\begin{array}{l}\text { Gasterosteus } \\
\text { aculeatus }\end{array}$ & $\begin{array}{l}\text { Alterations in } \\
\text { shoaling and } \\
\text { feeding } \\
\text { behaviour }\end{array}$ & $\begin{array}{l}\text { Wibe et al., } \\
2002\end{array}$ \\
\hline BPA & M. edulis & & $\begin{array}{l}\text { Increase of } \\
\text { phospho-protein } \\
\text { levels; spawning } \\
\text { induction in both } \\
\text { sexes; damage on } \\
\text { oocytes and } \\
\text { ovarian follicles; } \\
\text { rise in } \\
\text { micronuclei } \\
\text { frequency in gills }\end{array}$ & $\begin{array}{l}\text { Aarab et al., } \\
2006 ; \\
\text { Barsiene et } \\
\text { al., } 2006\end{array}$ \\
\hline & \multicolumn{2}{|c|}{ M. galloprovincialis } & $\begin{array}{l}\text { Destabilization of } \\
\text { the lysosomal } \\
\text { membrane in } \\
\text { hemocytes; } \\
\text { induction in the } \\
\text { phosphorylation } \\
\text { of mitogen- } \\
\text { activated protein } \\
\text { kinases and } \\
\text { signal } \\
\text { transducers and } \\
\text { activators of } \\
\text { transcription } \\
\text { factors }\end{array}$ & $\begin{array}{l}\text { Canesi et al., } \\
2005,2007 a\end{array}$ \\
\hline
\end{tabular}

Table 2 (Continued)

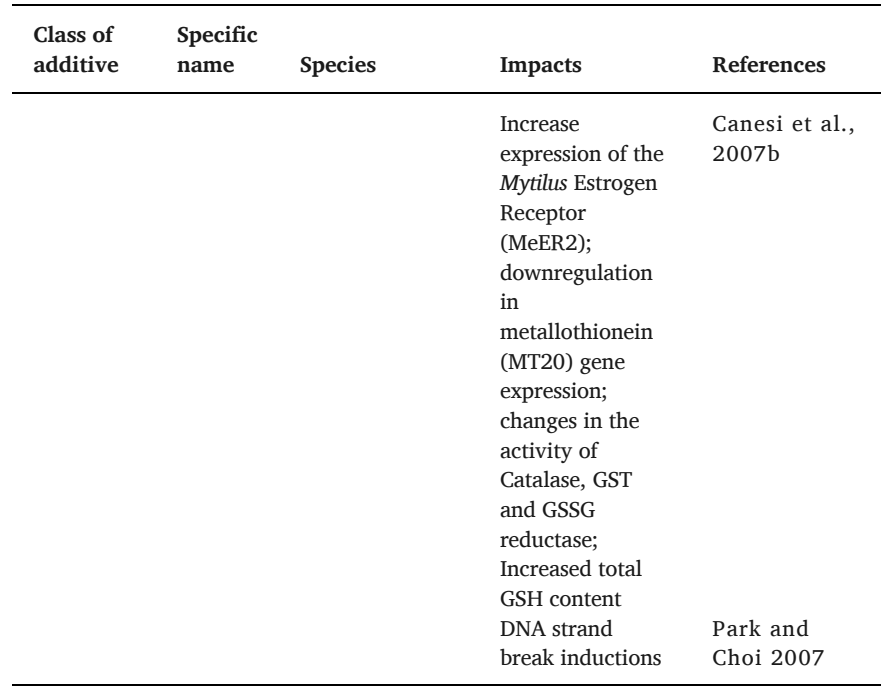

DEHP, Diethylhexyl phthalate; DAP, Diallyl phthalate; DBP, Dibutyl phthalate; BBP, Butyl benzyl phthalate; BPA, Bisphenol A; GST, Glutathione S-transferase; GSSG, Glutathione disulfide; GSH, gluthatione.

et al., 2016). Concentrations up to $16,444 \mathrm{ng} / \mathrm{g}$ were observed in MPs in the stomach of seabirds (Tanaka et al., 2013; 2015; Herzke et al., 2016). Phenols, such as BPA and NP, have been measured worldwide in field-collected MPs at a range of $1-730 \mathrm{ng} / \mathrm{g}$ and $5.8-16,000 \mathrm{ng} / \mathrm{g}$, respectively (reviewed by Hong et al., 2018), while phthalates have been detected in coastal PE, PP and PS MPs from China up to $80.4 \mathrm{ng} /$ $\mathrm{g}$, with diethylhexyl phthalate, DEHP, being the most concentrated class (up to $69.9 \mathrm{ng} / \mathrm{g}$ ) (Zhang et al., 2018). Metals have been detected in different types of MPs at ng/g levels (Ashton et al., 2010, Nakashima et al., 2012; Turner and Holmes, 2011). $\mathrm{Hg}$ and $\mathrm{Pb}$ showed values of $3.86 \mu \mathrm{g} / \mathrm{g}$ and $38.2 \mathrm{mg} / \mathrm{g}$ in EPS (Wang et al., 2017) and PVC fragments (Turner et al., 2020), respectively.

The desorption from plastic materials depends on several factors, including the type and strength of molecules-polymer binding, the internal pore size of the polymer, the additives' molecular weight and degree of hydrophobicity (Teuten et al., 2009). The additive leaching from plastic surface may also be influenced by the polymer texture, categorised in glassy, rubbery (amorphous) and crystalline (Brydson, 1999). Hahladakis et al. (2018) recently demonstrated that the leaching of additives from polymers showing crystalline texture is relatively low when compared to rubbery synthetic material. In order to evaluate the physicochemical properties governing the release of additives, Luo et al. (2019) analysed the leaching behaviour of fluorescent chemicals from polyurethane MPs in natural (river, lake, wetland, and sea

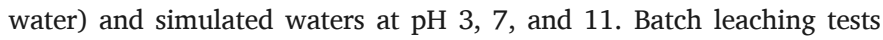
were conducted adding $0.7 \mathrm{~g}$ of MPs to $200 \mathrm{~mL}$ water at $25^{\circ} \mathrm{C}$. After reaching equilibrium, $2 \mathrm{~mL}$ of the solution containing the leachates were taken every hour up to $6 \mathrm{~h}$, and, thereafter, every $6 \mathrm{~h}$ up to $48 \mathrm{~h}$. The leachates were then analysed by fluorescence spectroscopy establishing the release kinetics of fluorescent additives from MPs. Within 12-24 h, the maximum amount of additives was released into the leachate, notably 3,3'-diaminobenzidine-like substances. The concentrations of fluorescent additives in simulated and natural waters followed the order of basic water $>$ neutral water $>$ seawater $>$ lake $>$ river $>$ wetland. These results suggest that additives may leach at higher rate in seawater compared to freshwater and, more importantly, that leaching processes may occur in relatively short time $(\leq 24 \mathrm{~h})$ after plastic disposal in aquatic systems. However, it is worth noting that the outcomes of artificial weathering do not necessarily match with those of natural in-situ weathering; hence, caution should be used when inferring experimental data to natural environment conditions. 


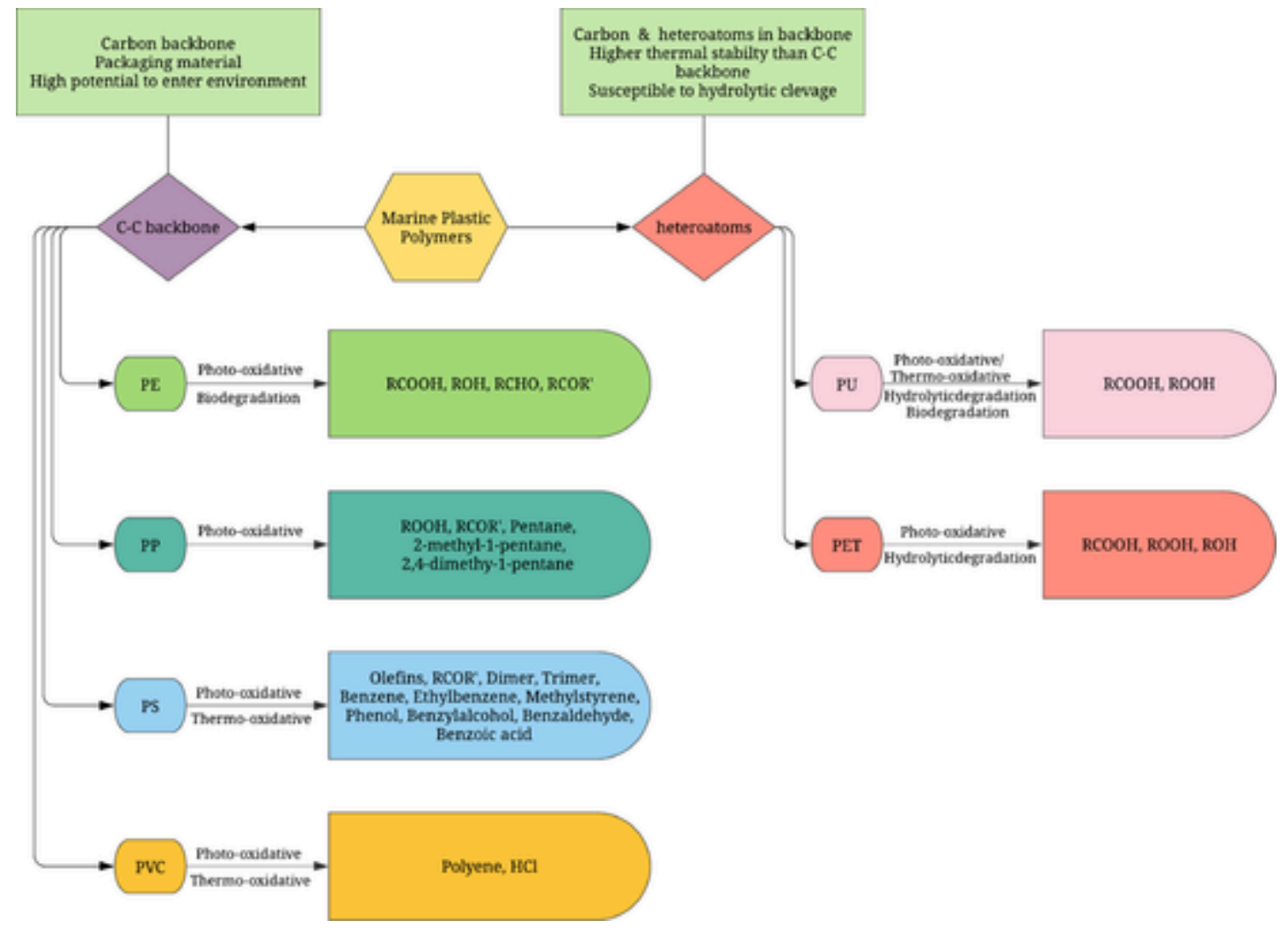

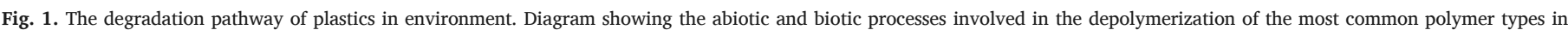

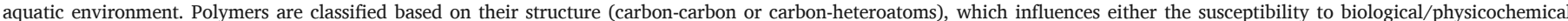
factors and the formation or release of organic by-products.

Organic additives used as plasticizers, stabilizers and flame retardants have frequently been detected in seawater in the past twenty years. NP showed concentrations ranging from $20 \mathrm{pg} / \mathrm{L}$ measured in the Sea of Japan to $4.1 \mu \mathrm{g} / \mathrm{L}$ in the Mediterranean Sea (Spain) (reviewed by Hermabessiere et al., 2017). Similar levels have been detected for BPA, with values ranging from 0.001 to $2.47 \mu \mathrm{g} / \mathrm{L}$ measured in the Jiaozhou Bay (China) and Singapore coastal waters, respectively (Basher et al., 2004; Fu et al., 2007). A significant amount of data is also available for phthalates esters, at levels from few $\mathrm{pg} / \mathrm{L}$ to tens of $\mu \mathrm{g} / \mathrm{L}$ in seawaters. Between the phthalates congeners, DEHP is most frequently detected in seawater, with levels from $448 \mathrm{pg} / \mathrm{L}$ (Arctic waters, Xie et al., 2007) to $23.42 \mu \mathrm{g} / \mathrm{L}$ (Sardinian waters, Italy; Fossi et al., 2012). Among BFRs, PBDEs have been detected from 0.002-19 ng/L in Hong-Kong and Mediterranean Sea, respectively (Sànchez-Avila et al., 2012; Wurl et al., 2006), while HBCDs showed levels between $0.1 \mathrm{pg}$ / $\mathrm{L}$ measured in the European Arctic waters and $1620 \mathrm{pg} / \mathrm{L}$ from South Korea (reviewed by Gu et al., 2017).

\subsection{Techniques employed for the chemical screening of plastic leachates}

A vast and heterogeneous array of inorganic and organic compounds are used as additives during plastic production, and, in most cases, their number, type and concentrations on polymers are unknown. As a result, it is rather challenging to analyse the chemical composition of plastic additive leachates, or even to define the suitable analytical approach to meet this purpose. A list of techniques used to identify the additives released by plastics following experimental leaching into aqueous media is reported in Table 3. Among tested chemicals, metals were the most successfully characterized in leachates using methods based on mass, atomic and optical spectroscopy (Capolupo et al., 2020; Lithner et al., 2012; Tetu et al., 2019). Methods previously validated for micro-sized plastics identification in environmen- tal samples, as the Fourier Transform Infrared Spectroscopy (FT-IR) and the Raman spectroscopy (Käppler et al., 2016; Shim et al., 2017) were adapted by Luo et al. (2019) to assess the plastic leachate organic chemical content. Peak positions were comparable to those of $3,3^{\prime}$-Diaminobenzidine, used as a model compound of organic additives, showing the presence of unidentified biphenyls in prepared leachates. Untargeted LC-MS screenings were also found to detect complex mixture of organic components, whilst not identifying specific compounds (Tetu et al., 2019). Capolupo et al. (2020) used a GC-MS approach based on the preliminary (non-target) additive characterization in plastic particles, which allowed to identify organic compounds likely to be released into the aqueous solution. The subsequent GC-MS analysis of prepared leachates corroborated the preliminary evidence, and allowed to evaluate the composition and concentrations of released organics, including BPA, benzothiazole, acetophenone n-cyclohexylformamide and phthalide (Capolupo et al., 2020).

\subsection{Plastic leachate preparation in ecotoxicity studies}

Standard methods for testing the leaching of solid materials have been developed and used extensively since the 1990s to assess the risks to public health from the release of high-toxicity contaminants. Among those methods, protocol D-7475-20 of the American Society for Testing and Materials (ASTM, 2020) has been successfully validated to investigate the leaching and biodegradation of plastic waste in a laboratory-scale bioreactor reproducing aerobic and anaerobic (bio)degradation processes occurring in a municipal solid-waste stream. Twenty-fourto forty-eight-hour leaching protocols in stirring conditions have further been recommended by the United States Environmental Protection Agency (US EPA) for dumped solid waste. Those include the standard leaching test (SLT), the international unit conversion system (IUCS) test and the Minnesota test, while the "DIN 38414-S4" method is cur- 


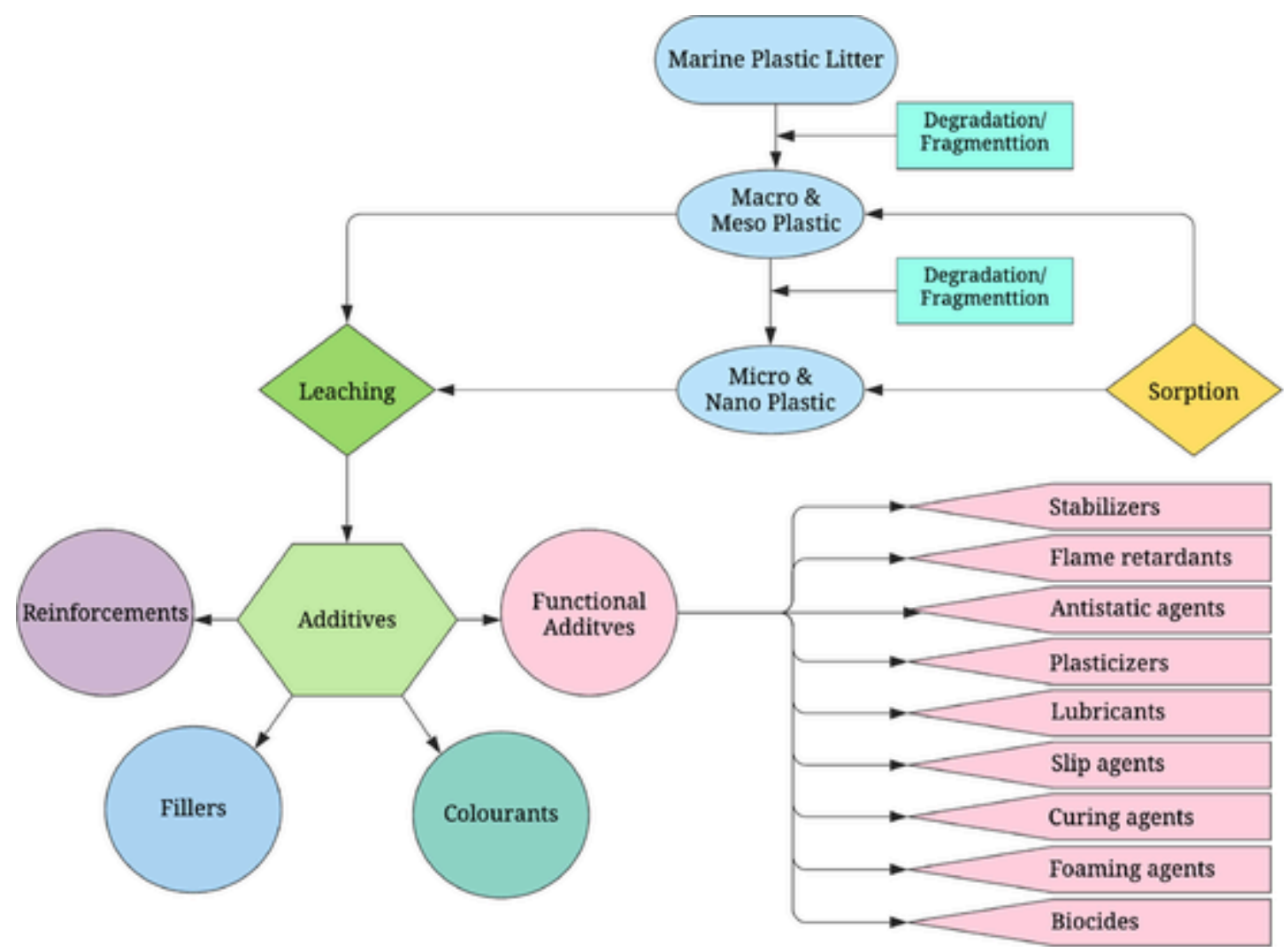

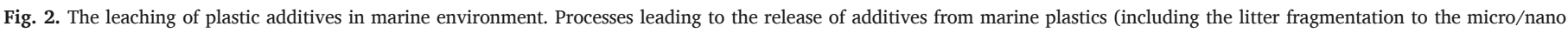
scale) and types of additives released by plastic leachates (according to Hansen et al., 2013).

rently recommended by the European Union (reviewed by Kocasoy and Murat, 2009). Although the leaching of plastic additives (e.g. BPA) has been first reported nearly twenty years ago (e.g. Yamamoto and Yasuhara, 1999; Sajiki and Yonekubo, 2003), studies addressing the adverse effects of whole plastic leachates on aquatic organisms have been published very recently, reflecting the increasing global concern about ocean contamination by plastic debris (UNEP, 2016; GESAMP, 2016). As summarized in Table 4, plastic leachates so far employed for ecotoxicity assessments have been generated using techniques differing by eluent nature, mass/volume ratio, duration, and temperature. A major factor limiting the definition and adoption of standard media for plastic leaching is due to the fact that current international guidelines for toxicity testing, notably those for algae growth, fish/mussel embryotoxicity or Daphnia magna acute and chronic tests (ASTM, 2012; OECD, 1992; 1998; 2004), require the use of specific aqueous matrices. Standard artificial fresh/seawater or cell culture media, for example, might influence the migration, toxicity and/or detection of desorbed additives. PVC, PP, PE and PS are the polymers most frequently tested for additive leaching (Table 4). However, leaching trials were conducted using a variety of commercial plastic products, beached and/ or virgin pellets which might deeply differ from each other in terms of additive quantity, composition and bioaccessibility, regardless of the polymer type.

Treatments in bioassays were generally represented by \% dilution of prepared leachates, but concentrations of plastic tested for additive leaching varied remarkably among studies, i.e. from $5 \mathrm{~g} / \mathrm{L}$ (1/200 solid/ liquid ratio; Tetu et al., 2019) to $250 \mathrm{~g} / \mathrm{L}$ (1/4 solid/liquid ratio; Lithner et al., 2012; Rummel et al., 2019). This made the comparative evaluation of data among performed tests, organisms and polymers difficult. Six out of the thirteen studies reported in Table 4 tested the leaching of plastics for 24-48 $\mathrm{h}$ in line with the US EPA and EU standard guidelines (Kocasoy and Murat, 2009), while prolonged leaching tests (3 to 28 days) were generally used elsewhere, except for
Thaysen et al. (2018) who prepared EPS leachates within 30 min at relatively high temperature $\left(70-90{ }^{\circ} \mathrm{C}\right)$. Additionally, only one study (Luo et al., 2019), investigated the effect of $\mathrm{pH}$ variations on the migration of additives from plastics. Hence, there is a clear need for a common guideline for the experimental preparation of plastic additive leachates. This might reproduce environmentally realistic conditions while meeting standard requirements for ecotoxicity testing. Major efforts are also necessary to identify plastic/medium ratios allowing for consistent estimations of additive leaching in aquatic systems and for standardized treatments in ecotoxicological studies to provide information useful to risk assessment and mitigation.

\section{Effects of plastic leachates on aquatic species from different trophic levels}

\subsection{Effects on photosynthetic microorganisms and marine plants}

According to recent estimates, nearly 23,600 metric tons/year of dissolved organic carbon (DOC) are released from marine plastics globally (Romera-Castillo et al., 2018). DOC plays a vital role in the marine trophic web by modulating the presence, growth and activity of photosynthetic and heterotrophic microorganisms (Azam et al., 1983a, b). The composition, interactions and functional diversity of the marine microbiota might thus experience severe alterations owing to the ever-growing prevalence of plastic in marine systems.

A handful of studies have recently been addressed to the effects of plastic leachates on phytoplanktonic or prokaryotic marine microorganisms (Table S1). Tetu et al. (2019) evaluated the effects of leachates from high dense PE shopping bags and PVC matting on two strains of the marine photosynthetic cyanobacterium Prochlorococcus spp. All leachates induced growth and genome-wide transcriptional changes after $72 \mathrm{~h}$ of exposure, as well as a reduction of the photochemical efficiency of photosystem II and a clear decline in oxygen production (Tetu et al., 2019). A recent study by Capolupo et 
Table 3

List of the methods employed to characterize the composition of plastic additive leachates

\begin{tabular}{ll}
\hline Techniques/tools & $\begin{array}{l}\text { Target } \\
\text { analysis/additive }\end{array}$ \\
\hline $\begin{array}{l}\text { Fourier Transform Infrared } \\
\text { Spectroscopy (FT-IR) }\end{array}$ & $\begin{array}{l}\text { physical (released } \\
\text { fragments) and } \\
\text { chemical (organic } \\
\text { compounds) } \\
\text { characterization of } \\
\text { leachates } \\
\text { organic compounds } \\
\text { from PVC and HDPE }\end{array}$ \\
Liquid Chromatography- & leachates \\
Tandem Mass spectrometry & metals in different \\
(LC-MS/MS) & polymer leachates \\
Inductively coupled plasma &
\end{tabular}

Inductively coupled plasma atomic emission spectroscopy (ICP-AES)

Inductively coupled plasma

optical emission spectroscopy (ICP-OES)

Gas Chromatography-Mass

Spectrometry (GC-MS)

Ultra-Performance Liquid Chromatography (UPLC-MS)

High-Performance Liquid

Chromatography - High-

Resolution Accurate Mass-

Mass Spectrometer (HPLC-

HR-AM-MS)

$\mathrm{X}$-ray photoelectron

spectroscopy (XPS)

Raman Spectrometer (RS)

nanoparticles from

plastic teabags

screening of organic

compounds in PUF

leachates

Reference(s)

Hernandez et al.,

2019; Luo et al.

2019

Tetu et al., 2019

Capolupo et al., 2020; Lithner et al. 2012; Schiavo et al., 2020; Tetu et al., 2019

Lithner et al., 2012

Tetu et al., 2019

Capolupo et al., 2020; Schiavo et al., 2020; Thaysen et

al. 2018

Bejgarn et al., 2015

Li et al., 2016

Hernandez et al. 2019

Luo et al., 2019
PVC, polyvinyl chloride; HDPE, high-density polyethylene; PUF, Polyurethane Foam; ESI, electrospray

Ionization.

al. (2020) addressed the chemical composition and effects of leachates from car tire rubber (CTR), PP, PET, PS and PVC. CTR, PVC, PP and PS leachates significantly inhibited the growth of the marine microalga Skeletonema costatum $\left(\right.$ ECs $_{50}$ in the range of $18-34 \%$ of leachate), while PET did not cause growth inhibition even at the $100 \%$ leachate concentration. The combination of non-target and target (GC-MS) analyses revealed clear relationships between observed effects and relatively high concentrations (up to $\mathrm{mg} / \mathrm{L}$ ) of organic compounds (i.e plasticizers, antioxidants, antimicrobials, lubricants, and vulcanizers) and metals (notably $\mathrm{Zn}, \mathrm{Cu}, \mathrm{Co}, \mathrm{Sb}$ and $\mathrm{Pb}$ ) in the leachates (Capolupo et al., 2020). Leachates from EPS consisting in an aqueous mixture of hexabromocyclododecane (HBCD), BPA and bumetrizole (UV 326), were recently found to up-regulate the photosynthetic processes in marine microalgae, including Dunaliella salina, Scenedesmus rubescens, Chlorella saccharophila, and Stichococcus bacillaris (Chae et al., 2020). This contrasts with data previously reported by Sjollema et al. (2016), who did not observe changes in the photosynthetic activity of Dunaliella and Chlorella spp. following exposure to PS micro-particles, corroborating the importance of (preliminary) experimental leaching processes to reliably assess the toxicity of desorbed additives.

A laboratory experiment was set up by Menicagli et al. (2019) to analyse the effects of leachates from conventional undegradable bags (high density polyethylene - HDPE) and a new generation of compostable bags on the coastal dune plants Thinopyrum junceum and Glau- cium flavum. The leaching process altered properties of water in terms of $\mathrm{pH}$ and salinity; the timing of seed germination and seedling growth was altered by the exposure to leachate from both plastic materials. Moreover, seedling anomalies were observed in both species, posing the accent on the possible impact of leachates from beached plastic litter during rainfall events or tide fluctuations.

Overall, these studies show that the impact of plastic leachates on marine phytoplanktonic microorganisms and marine plants varies considerably depending on tested species and materials. Changes have been observed for what concerns growth, photosynthetic activity and gene transcription, urging the need for a better understanding of the risks posed by plastic additive mixtures on the microbial processes governing primary production and on the ecosystem services warranted by coastal vegetation.

\subsection{Effects on marine fauna}

Several functions were found to be impaired in marine invertebrates and vertebrates after exposure to plastic leachates, as schematically summarised in Table S1.

Sessile marine invertebrates are organisms of choice for testing the effects of plastics on coastal habitats, since they generally display filter/ deposit feeding habits, which naturally exposed them to the ingestion of a potentially high amount of non-food items, rapid responsiveness to external stressors and a notable adaptability to laboratory conditions.

Recently, the increasing concerns on plastic ingestion and effects raised awareness on the impact of additive leachates on early swimming stages of benthic and intertidal organisms, some of which are known to be highly sensitive to organic additives, as BPA (Balbi et al., 2016). In a recent investigation by Ke et al. (2019) the toxicity of leachates from two single-use PE bags was assessed on early stages of the yellow clam Meretrix meretrix. Leachates did not induce alterations of the clam gamete fertilisation; however, embryonic development, shell height and survival of D-veliger larvae were significantly impaired after exposure to leachates from both plastic bag materials. Embryo-larval development of the brown mussel Perna perna was impaired by leachates from virgin and beached PP microplastics (Gandara and Silva et al., 2016). A relatively higher toxicity was assigned to beached materials, likely owing to the presence of adsorbed pollutants which may have cumulatively increased the toxicity of additive leachates. The Mediterranean mussel Mytilus galloprovincialis was also employed as model organism to screen the toxicity of leachates from PET, PS, PP, PVC and car tire rubber (Capolupo et al., 2020). Cellular endpoints, as the hemocyte lysosomal membrane stability, and early stages parameters as gamete fertilization, embryonic development, larvae motility and survival were deeply affected by the exposure to all tested leachates. Embryonic development was the most sensitive parameter, with effects of leachates ranked as CTR > PVC > PP > PS > PET. Considering the composition of the different leachates, acetophenone, benzothiazole, n-cyclohexylformamide, phthalide, and BPA were found at the highest concentrations (13.2; 1460; 788; 2.4; and $6.4 \mu \mathrm{g} / \mathrm{L}$, respectively) in CTR leachates. Among them, BPA is known to exert transcriptional and embryotoxic effects in $M$. galloprovincialis in line with its endocrine disrupting activity (Balbi et al., 2016); benzothiazole and phthalide have previously been reported to induce embriotoxicity (Sheftel, 2000).

Survival and settlement of early stages of the barnacle Amphibalanus amphitrite were investigated after exposure to increasing concentrations $\left(0.004\right.$ to $\left.0.5 \mathrm{~m}^{2} / \mathrm{L}\right)$ of leachates from high density polyethylene (HDPE), low density polyethylene (LDPE), PP, PVC, PC, PET and PS by Li et al. (2016). The barnacle cyprids settlement was inhibited at all tested concentrations, while the survival of exposed nauplii decreased at the highest dosage. PVC leachates showed the highest toxicity among tested solutions, followed by LDPE. The HPLC-HR/AM MS screening revealed the presence of numerous electrospray ionization (ESI) amenable organic substances in leachates, although single-com- 
Table 4

Methods used for plastic leachate preparation in ecotoxicity studies.

\begin{tabular}{|c|c|c|c|c|c|c|c|c|c|}
\hline Tested species & Polymer & $\begin{array}{l}\text { [Leaching } \\
\text { plastic] }\end{array}$ & Medium & Duration & illumination & $\mathbf{T}^{\circ}$ & $\mathrm{pH}$ & Filtration & References \\
\hline Prochlorococcus spp. (bacteria, SW) & HDPE/PVC & $\begin{array}{l}25-1.6 \mathrm{mg} / \\
\mathrm{mL}(\mathrm{HDPE}) \\
5-0.125 \mathrm{mg} / \\
\mathrm{mL}(\mathrm{PVC})\end{array}$ & $\begin{array}{l}\text { SW } \\
\text { (AMP1 } \\
\text { cell } \\
\text { culture } \\
\text { medium) }\end{array}$ & 5 days & yes & $22^{\circ} \mathrm{C}$ & - & $0.2 \mu \mathrm{m}$ & $\begin{array}{l}\text { Tetu et } \\
\text { al., } 2019\end{array}$ \\
\hline $\begin{array}{l}\text { Mytilus galloprovincialis (mussel, SW); } \\
\text { Skeletonema costatum (algae, SW); } \\
\text { Raphidocelis subcapitata (algae, FW) }\end{array}$ & $\begin{array}{l}\text { PET, PS, PP, } \\
\text { PVC, CTR }\end{array}$ & $80 \mathrm{~g} / \mathrm{L}$ & $\begin{array}{l}\text { FW/SW } \\
\text { culture } \\
\text { medium } \\
\text { (algae); } \\
\text { filtered } \\
\text { seawater } \\
\text { (mussels) }\end{array}$ & 14 days & no & $25^{\circ} \mathrm{C}$ & $\begin{array}{l}7.8 \\
(\mathrm{FW})-8.1 \\
(\mathrm{SW})\end{array}$ & $0.2 \mu \mathrm{m}$ & $\begin{array}{l}\text { Capolupo } \\
\text { et al., } \\
2020\end{array}$ \\
\hline Amphibalanus amphitrite (barnacle, SW) & $\begin{array}{l}\text { PET, HDPE, } \\
\text { PVC, LDPE, } \\
\text { PP, PS, PC }\end{array}$ & $0.5 \mathrm{~m}^{2} / \mathrm{L}$ & $\begin{array}{l}\text { filtered } \\
\text { aged } \\
\text { seawater }\end{array}$ & $24 \mathrm{~h}$ & & $28^{\circ} \mathrm{C}$ & 7.96 & - & $\begin{array}{l}\text { Li et al., } \\
2016\end{array}$ \\
\hline Paracentrotus lividus (sea urchin, SW) & PVC & $100 \mathrm{~g} / \mathrm{L}$ & $\begin{array}{l}\text { Artificial } \\
\text { seawater }\end{array}$ & $24 \mathrm{~h}$ & no & $20{ }^{\circ} \mathrm{C}$ & 8.1 & $1.2 \mu \mathrm{m}$ & $\begin{array}{l}\text { Oliviero } \\
\text { et al., } \\
2019\end{array}$ \\
\hline Nitocra Spinipes (copepod, SW) & $\begin{array}{l}\text { PP, PS, LDPE, } \\
\text { HDPE, PVC, } \\
\text { PET, PLA, } \\
\text { Nylon, bio- } \\
\text { PET, corn } \\
\text { starch/ } \\
\text { aliphatic esters } \\
\text { (bio) }\end{array}$ & $10 \mathrm{~g} / 100 \mathrm{~mL}$ & $\begin{array}{l}\text { Brackish } \\
\text { water } \\
\text { from the } \\
\text { Baltic Sea }\end{array}$ & $92 \mathrm{~h}$ & - & - & 7.9 & - & $\begin{array}{l}\text { Bejgarn et } \\
\text { al., } 2015\end{array}$ \\
\hline Littorina littorea (snail, SW) & PP & $20 \mathrm{~mL} / \mathrm{L}$ & SW & $24 \mathrm{~h}$ & & & & & $\begin{array}{l}\text { Seuront, } \\
2018\end{array}$ \\
\hline \multirow[t]{2}{*}{ Daphnia magna (cladoceran, FW) } & $\begin{array}{l}\text { PC, PVC, PU, } \\
\text { PE, PS LDPE, } \\
\text { HDPE, PET, } \\
\text { PMMA, PTFE, } \\
\text { ABS, PP, } \\
\text { MDPE }\end{array}$ & $65-174 \mathrm{~g} / \mathrm{L}$ & $\begin{array}{l}\text { deionized } \\
\text { water }\end{array}$ & $\begin{array}{l}24 \mathrm{~h}-3 \\
\text { days }\end{array}$ & $\begin{array}{l}\text { 16h: 8h, L:D; } \\
\text { darkness }\end{array}$ & $20 \pm 2{ }^{\circ} \mathrm{C}$ & 7 & $\begin{array}{l}\text { fine nylon } \\
\text { fabric }\end{array}$ & $\begin{array}{l}\text { Lithner et } \\
\text { al., } 2009\end{array}$ \\
\hline & $\begin{array}{l}\text { PP, HDPE, } \\
\text { PVC, ABS, } \\
\text { epoxy }\end{array}$ & $250 \mathrm{~g} / \mathrm{L}$ & $\begin{array}{l}\text { deionized } \\
\text { water }\end{array}$ & 3 days & dark & $20-50{ }^{\circ} \mathrm{C}$ & 7 & - & $\begin{array}{l}\text { Lithner et } \\
\text { al., } 2012\end{array}$ \\
\hline Ceriodaphnia dubia (cladoceran, FW) & PS, EPS & & FW & $30 \mathrm{~min}$. & & $70-90{ }^{\circ} \mathrm{C}$ & & - & $\begin{array}{l}\text { Thaysen } \\
\text { et al., } \\
2018\end{array}$ \\
\hline $\begin{array}{l}\text { Daphnia magna (cladoceran, FW); } \\
\text { Sorghum saccharatum, Lepidium sativum, } \\
\text { Sinapis alba, Vicia faba (plants, FW); } \\
\text { Vibrio fischeri (bacteria, FW/SW) }\end{array}$ & $\begin{array}{l}\text { PE, PP, PS, } \\
\mathrm{PE}_{\mathrm{a}}, \mathrm{PP}_{\mathrm{a}}, \mathrm{PS}_{\mathrm{a}}\end{array}$ & $10: 1(\mathrm{~L} / \mathrm{S})$ & $\begin{array}{l}\text { Milli-Q } \\
\mathrm{H}_{2} \mathrm{O}\end{array}$ & $24 \mathrm{~h}$ & dark & $\begin{array}{l}20 \pm \\
2{ }^{\circ} \mathrm{C}\end{array}$ & & $\begin{array}{l}11 \mu \mathrm{m} \\
\text { (Whatman } \\
\text { Grade 1) }\end{array}$ & $\begin{array}{l}\text { Schiavo } \\
\text { et al., } \\
2018 \\
2020\end{array}$ \\
\hline Chlorella vulgaris (algae, FW) & PUF & $0.7 \mathrm{~g} / 200 \mathrm{~mL}$ & $\begin{array}{l}\text { deionized, } \\
\text { tap and } \\
\text { natural } \\
\text { water; } 0.1 \\
\mathrm{M} \mathrm{NaCl}\end{array}$ & $48 \mathrm{~h}$ & & $25^{\circ} \mathrm{C}$ & $3,7,11$ & $0.45 \mu \mathrm{m}$ & $\begin{array}{l}\text { Luo et al., } \\
2019\end{array}$ \\
\hline $\begin{array}{l}\text { Dunaliella salina, Scenedesmus rubescens, } \\
\text { Chlorella saccharophila, Stichococcus } \\
\text { bacillaris (algae, SW) }\end{array}$ & EPS & $\begin{array}{l}0.1 \mathrm{~g}, 10 \text { and } \\
30 \mathrm{spheres/} \\
50 \mathrm{~mL}\end{array}$ & $\begin{array}{l}\text { culture } \\
\text { medium }\end{array}$ & 28 days & 16h: 8h, L:D & $20^{\circ} \mathrm{C}$ & - & $0.45 \mu \mathrm{m}$ & $\begin{array}{l}\text { Chae et } \\
\text { al., } 2020\end{array}$ \\
\hline Meretrix meretrix (clam, SW) & PE bags & $10 \mathrm{~g} / \mathrm{L}$ & $\begin{array}{l}\text { filtered } \\
\text { SW }\end{array}$ & $48 \mathrm{~h}$ & dark & $25^{\circ} \mathrm{C}$ & - & $\begin{array}{l}\text { fine nylon } \\
\text { fabric }\end{array}$ & $\begin{array}{l}\text { Ke et al., } \\
2019\end{array}$ \\
\hline Guine pig and rat cell lines & $\begin{array}{l}\text { PET, PE, PP, } \\
\text { PS }\end{array}$ & $50 \mathrm{~g} / 200 \mathrm{~mL}$ & $\begin{array}{l}\text { artificial } \\
\text { SW }\end{array}$ & $96 \mathrm{~h}$ & $\mathrm{UV}+$ light & $20-30{ }^{\circ} \mathrm{C}$ & - & $40 \mu \mathrm{m}$ & $\begin{array}{l}\text { Rummel } \\
\text { et al., } \\
2019\end{array}$ \\
\hline
\end{tabular}

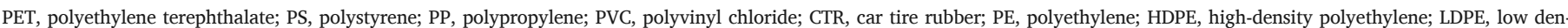

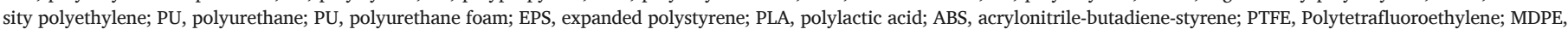

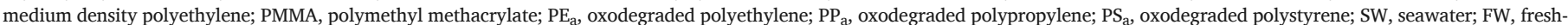
water: $\mathrm{L} / \mathrm{S}$, Liquid to Solid ratio.

pound characterizations were not performed. A study performed by Oliviero et al. (2019) investigated the toxicity of leachates from micronized commercial PVC products (children toys) of three different colours, upon embryos of the sea urchin Paracentrotus lividus. Leachate concentrations as low as 3.3\% significantly inhibited the larval growth, while higher dosages (33\%) lead to a substantial and generalized block of the ontogenesis. Based on the chemical screening of the prepared leachates, authors were able to relate observed effects to the degree of heavy metals leaching, with $\mathrm{Pb}, \mathrm{Zn}, \mathrm{Mn}, \mathrm{V}$ and Sc detected in the $\mu \mathrm{g}$ $\mathrm{mg} \mathrm{L^{-1 }}$ range.

Bejgarn et al. (2015) evaluated the effects of leachates from twenty-one commercial plastic products made of different polymeric materials on the marine harpacticoid copepod Nitocra spinipes. Eight out of the twenty-one tested leachates, used before and/or after artificial sunlight irradiation, affected the copepod survival. Lowest $\mathrm{LC}_{50}$ were measured for computer case-derived leachate $(15 \%$ leachate before irradiation) biodegradable bags (24-18\% leachate before-after irra- 
diation). Interestingly, DVD cases took 196-hour irradiation to produce toxic leachate, while PS cup did not show any toxicity after the same treatment, although both are made of amorphous polymers. Analyses for the presence of PVC residues proved that the leachates were a complex mixture of elements but did not show evidence of degradation of the polymer backbone. Leachates from soft PVC products containing relatively higher proportion of plasticizers were found to be toxic for $N$. spinipes while leachates from PVC products with lower amount of plasticisers were ineffective.

The response of marine organisms to chemosensory cues to escape from predation may also be significantly affected by plastic leachates. This has been observed in the common winkle Littorina littorea, exposed to leachates from virgin PP beads and beached plastic pellets (Seuront, 2018). Notably, in the presence of predator chemical cues from the shore crab Carcinus maenas, the time spent in refuge or employed for righting and withdrawal of $L$. littorea was reduced, indicating an overall inhibition of predator-induced alertness and avoidance responses. The effects induced by the post-ingestion leaching of additives from PVC particles were assessed in the lugworm Arenicola marina by Browne et al. (2013). After a 10-day exposure, substances including nonylphenol, phenanthrene, triclosan and PBDE-47 were detectable in the gut tissue from few $\mu$ (nonylphenol, phenantrene) to $\mathrm{mg}$ (triclosan) $\mathrm{g}^{-1}$. A > $60 \%$ reduction of the coelomocyte phagocytic activity toward pathogens was related to the nonylphenol uptake. Uptake of triclosan inhibited the worm burrowing activity and caused a $>55 \%$ increased mortality, while PVC particles alone made worms $>30 \%$ more susceptible to oxidative stress.

The knowledge on the effects of plastic additives leachates on marine fish is still very limited compared to invertebrates or microorganisms. Evidence of toxicity due to additive migration has been obtained in the orchid dottyback Pseudochromis fridmani exposed to the non-ionic surfactant nonylphenol leached from FDA food-grade PE bags. Nonylphenol leached up to about $160 \mu \mathrm{g} / \mathrm{L}$ after $48 \mathrm{~h}$ of plastic-water interaction and tended to bioaccumulate in fish tissue at levels (up to $369 \mu \mathrm{g} / \mathrm{Kg}$ ) found to be positively related with short- and long-term mortality $(60 \%$ and $100 \%$, respectively) (Hamlin et al., 2015).

The studies on seabirds raise a new concern, about the possibility that stomach fluids enhance leaching of additives after ingestion of plastic particles. Feeding experiments with polystyrene plastic pellets compounded with five additives provided direct evidence of the transfer of flame retardants and ultraviolet stabilizers to the abdominal adipose tissue and to the liver of chicks of Calonectris leucomelas (Tanaka et al., 2020). By day $15-16,42$ to $88 \%$ of the additives were leached out from the stomach and found at significant concentrations (up to 120,000 times the rate compared to the natural diet) in the tissues. The Authors hypothesised that stomach oil, which is present in the digestive tract of marine birds, acts as an organic solvent facilitating the leaching of hydrophobic chemicals. These data underscore the importance of plastic debris as a growing source of pollutants after ingestion.

Additional data are provided by studies on lugworm (Arenicola marina) and North Sea cod (Gadus morhua) to evaluate the potential for leaching of nonylphenol (NP) and bisphenol A (BPA) in their intestinal tracts (Koelmans et al., 2014). The Authors used a biodynamic model that allows calculating the relative contribution of ingesting plastic to the total exposure of aquatic species to chemicals within the ingested plastic. They accounted for uncertainty in the most crucial parameters through probabilistic modelling. Differently from the abovementioned studies by Tanaka et al. (2020), plastic ingestion appeared to be a negligible pathway for exposure to NP and BPA in lugworm and cod. However, these investigations highlighted the need for a precise methodological setup, a system at equilibrium, and the use of uncontaminated organisms as experimental models to obtain high quality results.

Leachate ecotoxicity studies in the literature have mainly been addressed to apical endpoints (i.e. mortality, decreased growth and feeding, and reproduction failure). To our knowledge, the work by Tre- strail et al. (2020) is the first to provide insights into toxicity mechanisms. It addressed the responses to phenol-formaldehyde MPs generated by two types of phenol-formaldehyde foams, and compared the biological effects with those of the MP leachates obtained from freshly crushed foam microplastics ( $50 \mathrm{mg} \mathrm{MP} / \mathrm{mL}$ distilled water) after shaking for $24 \mathrm{~h}$ at $25^{\circ} \mathrm{C}$. The leachates from regular foam and bio-foam microplastics showed acute toxicity to Artemia nauplii and D. magna after 24-h exposures, with $\mathrm{LC}_{50}$ in the range of $15-27 \mathrm{mg} / \mathrm{mL}$. Bio-foam MPs were more toxic than regular foam MPs for zebrafish embryos ( $\mathrm{LC}_{50} 43.8$ vs $27.1 \mathrm{mg} / \mathrm{mL}$, respectively). The same work also addressed sublethal responses in mussels, $M$. galloprovincialis, related to oxidative stress. No statistically significant effects were observed for the leachates, the leachate + MPs and MPs alone on catalase and GST activities. Instead, small but significant increase of acetylcholinesterase activity were observed after treatment with leachate + MPs and MPs alone. Moreover, no effects were observed after exposure to leachate alone, while significant decrease of lipid peroxidation were observed after treatment with leachate + MPs and MPs alone. As the authors mentioned, variables such as age, seasonality and feeding regime may influence the biomarker responses and eventually obscure the effects of treatments. This is the reasons why there are several recommendations on the choice of sentinel organisms and battery of biomarkers (Viarengo et al., 2007). The time of exposure was only three days; most importantly, the whole soft tissue was used for analysis. Because of the different exposure to waterborne contaminants, the responses of mussel gills and digestive gland are higher than those of other tissues; moreover, some biomarkers are more responsive in gills than digestive glands or vice-versa. In conclusion, the work by Trestrail et al. (2020) opens the way to studies on leachate toxicity mechanisms, although the experimental approach may be improved. More investigations at the molecular and cellular level are then advisable to understand the molecular initiating event of leachate adverse effects. For completeness, we mention that also investigation on MPs have privileged apical endpoints, and more studies on toxicity mechanisms are needed to improve the reliability of the Adverse Outcome Pathways (AOP) applicable to MP management (Jeong and Choi, 2019).

\subsection{Effects on freshwater organisms}

Most of the plastic discharged in natural environment finally find its way to marine waters through freshwater hydrological systems, as streams lakes or rivers (GESAMP, 2016). Recent monitoring studies have established that MPs are ubiquitously found in freshwater matrices. Report on rivers and lakes are far from complete, and especially lack for African and Australian waters. Also, data are often reported using different units, which make comparisons difficult. To provide an order of magnitude, the most polluted river is the Yang-Tze with 1660-8925 particles $/ \mathrm{m}^{3}$. In Europe, 22 particles $/ \mathrm{m}^{3}$ were reported in the Danube river, 0.35 particles $/ \mathrm{m}^{3}$ were reported in the Seine river. For a comparison with marine waters, average values of 0.94 particles $/ \mathrm{m}^{3}$ were reported for the Mediterranean Sea, 1.7 for the Atlantic Sea, 3.7 for the Indian Ocean, 1200 for the Black Sea (reviewed by Waldschläger et al., 2020).

The environmental release of MPs into rivers and lakes occur from a wide variety of sources, including emissions from wastewater treatment plants, which bring into the surface waters mixtures of micro and nano-sized particles mainly from personal care products. Freshwater ecosystems are thus expected to be consistently exposed to flows of organic and inorganic additives, posing serious threats to the fitness of biota. A study by Schmidt et al. (2020) estimated that 5 to 54 metric tons per year of dissolved organic plastic additives of emerging concern are exported to the Gulf of Lion by the Rhone River. Phthalates were the most abundant class of additives, with concentrations ranging from 97 to $541 \mathrm{ng} / \mathrm{L}$, followed by organophosphate esters (85-265 ng/L) and bisphenols (4-21 ng/L). Nevertheless, only a few studies were done to assess leachate toxicity in freshwater organisms (Table S1). 
One of the first investigations on freshwater species (and on leachates in general) was performed by Lithner et al. (2009), who tested the effects of leachates from plastic products on the mobility of the cladoceran Daphnia magna using two different leaching techniques (batch and diffusion tests). Nine out of the 32 tested leachates lead to 48-h ECs50 ranging from 5 to $80 \mathrm{~g}$ plastic material per litre, with compact disc material resulting as the most toxic due to the presence of silver layer(s). In a further study, Lithner et al. (2012) compared the effects of leachates from PP, HDPE, PVC, acrylonitrile- butadiene-styrene (ABS), and epoxy (for a total of 26 plastic products) on D. magna. PVC and epoxy coatings were recorded as the most toxic, with ECs50 for immobilization ranging from 2 to $235 \mathrm{~g} / \mathrm{L}$. The leachate from 1 out of 5 HDPE products (watering can) also induced effects in the range of 17-24 g/L, while none of the leachates from PP and ABS showed toxicity. Chemical analyses confirmed the enrichment of metals in leachates from PVC laboratory gloves, notably Sn and Zn, which showed up to 1600 -fold enrichment. It emerges therefore the importance of additives identification to support a correct risk assessment of plastics, and the fact that additives play a major role in plastic toxicity.

The chronic effects of flexible polyvinylchloride (PVC), containing the plasticizer diisononylphthalate (DiNP), and of the rigid PVC, lacking DiNP, were evaluated on D. magna and compared after a 31-day exposure (Schrank et al., 2019). No mortality was induced, but flexible PVC increased animal body length and a reduced number of offspring. The leachate from the flexible PVC contained $2.67 \mu \mathrm{g} / \mathrm{L}$ DiNP. Interestingly, the Authors reported that in a previous study the plasticizer DiNP did not show any effect on $D$. magna after a 21-day exposure, even though used at a significantly higher concentration. This observation underlines two aspects: i) possibly, when more substances are present in the same mixture, they may lead to synergistic effects; (Schrank et al. (2019) only measured DiNP in the leachate, where eventually further substances could have been present); ii) standard protocols requiring a chronic exposure of 21-days may be not adequate to evaluate the effects of the mixture of substances occurring in leachates.

Recent studies by Schiavo et al. $(2018,2020)$ allow comparing the effects triggered by leachates from conventional PE, PP and PS, and those obtained from their oxo-degradable counterparts. These were made by complexing the original polymers with natural molecules able to swift their fragmentation. Based on data from cladocerans (D. magna), plants (Sorghum saccharatum, Lepidium sativum, Sinapis alban and Vicia faba) and bacteria (Vibrio fischeri), the Authors assigned an overall higher toxicity index (Test Battery Integrated Index, TBI) to oxo-degraded plastic leachates (10.9-22\%, Schiavo et al., 2020) with respect to those from virgin polymers (4-12.4\%, Schiavo et al., 2018). Furthermore, toxicity trends of leachates from conventional and modified polymers were opposite (PE > PS > PP for oxo-degraded, PP $>$ PS $>$ PE for virgin plastic leachates), apparently reflecting the changes in the release of metal additives confirmed using ICP-MS (Schiavo et al., 2018, 2020).

Using zebrafish, Danio rerio, as the model organism Boyle et al. (2020) reported that the exposure to PVC MPs caused an increase in expression of metallothionein transcript ( $m t 2)$ in zebrafish larvae, while levels of other transcripts ( $v t g$, and cyp $1 a$, related to related to estrogen and organic contaminant occurrence, respectively) were not affected. Because the effect was mitigated by washing the PVC in acid prior to zebrafish exposures, it was attributed to the presence of metals in the PVC leachate. In fact, a labile $\mathrm{Pb}$ additive occurred in the leachates and it was further released into water during the experimental trials. After $24 \mathrm{~h}$, an estimated $2.5 \%$ of the total acid-labile fraction of $\mathrm{Pb}$ was released into water from the PVC particles, indicating that PVC may serve as a source of $\mathrm{Pb}$ for longer than the $24 \mathrm{~h}$ of the experimental trials. This also suggests that ingestion of PVC could lead to freeing $\mathrm{Pb}$ once exposed to the acidic environment of the vertebrate stomach. The acid environment of the stomach of fish has also been shown to free MP-sorbed metal co-contaminants (Khan et al., 2017). Overall, the response of zebrafish to acid-washed PVC indicated that MPs were of negligible toxicity once the $\mathrm{Pb}$ additive was removed. This can be true for many other plastics, thus the identification of hazardous leachates is of great importance for plastic risk assessment.

Environmental conditions of freshwater systems vary considerably daily or seasonally. This is particularly evident in lakes, ponds and streams, where low water renewal rates and frequent physico-chemical fluctuations might effectively influence additive leaching from weathering plastics. Temperature oscillations, for instance, might regulate either the additive desorption from polymers or their environmental concentration by indirectly shaping the plastic/water ratio. However, the current knowledge on the influence of temperature on chemical composition and effects of plastic leachates is limited. One of the few investigations providing clues on these aspects was performed by Thaysen et al. (2018), who assessed the chemical composition and toxicity of additives leached from EPS products treated at $70-95^{\circ} \mathrm{C}$ for $30 \mathrm{~min}$. Styrene, ethylbenzene, toluene, benzene, meta- and para-xylene, isopropylbenzene, and isopropyltoluene were detected in the leachates at concentrations in the order of the $\mu \mathrm{g} / \mathrm{L}$. Moreover, produced leachates, notably that from EPS coffee/broth cups, lead to a reduction of the reproductive output and a $40 \%$ mortality in the (fresh)water flea Ceriodaphnia dubia (Thaysen et al., 2018). Although the tested temperatures are definitely out of the environmental range, these findings suggest that the raise of average temperatures, as expected due to global changes, might influence the migration of additive from weathering plastics, producing unexpected impacts on freshwater habitats.

As for marine organisms, freshwater investigations on leachate toxicity have been addressed to apical endpoints. However, it is known that the alteration of algal photosynthetic activity is the mechanism at the basis of reduced algal growth. A recent investigation by Luo et al. (2019) assessed the effects of leachates from polyurethane sponge microplastics on the freshwater green alga Chlorella vulgaris. Five-day incubation at the highest tested leachate concentration $(1.6 \mathrm{~g} / \mathrm{L})$ resulted in a $10.3 \%$ growth inhibition and a $51 \%$ decrease of the photosystem II maximum quantum efficiency, corroborating risks for primary producers previously highlighted on marine phytoplanktonic microorganisms. Authors also noted a $\mathrm{pH}$-dependent pattern of additive migration, with initial release rates being higher at $\mathrm{pH} 11.0$ compared to 7.0 and 3.0. These data appear to be of great ecological relevance because of the highly variable buffering capacity of freshwater systems that might generate $\mathrm{pH}$ variations leading, as stated by Luo et al. (2019), to changes in the additive desorption from weathering plastics. Alternatively, the plastic additive migration into freshwater medium could modify $\mathrm{pH}$ conditions, exposing organisms to the dual effect of chemical and physical stressors. For instance, evidence obtained by Capolupo et al. (2020) showed that the 14-day leaching of PVC, PP, PS PET and CTR (S/L ratio of $80 \mathrm{~g} / \mathrm{L}$ ) in freshwater medium ( $\mathrm{pH} 7.8$ ) lead to relevant $\mathrm{pH}$ variations, spanning from 6.8 (CTR) to 11.4 (PS), while lower changes (from 7.5 for CTR to 9.4 for PS leachates) occurred in seawater. Freshwater leachates had an overall greater effect on the algae growth (Pseudokirchneriella subcapitata; ECs 50 0.5-64\% leachates) than seawater leachates (S. costatum, ECs s0 $_{50} 18.1$ - > 100\% leachates) and showed a substantially higher migration of organic additives as BPA, acetophenone and benzothiazole, and metals as $\mathrm{Al}, \mathrm{Mn}, \mathrm{Sr}, \mathrm{Cd}, \mathrm{Ni}$ and $\mathrm{Co}$.

Overall, studies addressing the effects of plastic additive leachates on freshwater species are yet limited to a few numbers of species and scarce information is available on highly representative taxa, such as fish. Based on the very recent literature, it is becoming evident that parameters as temperature and $\mathrm{pH}$ can relevantly shape the intensity of chemical leaching in these environments, although the associated effects on organisms remain unexplored. Therefore, further efforts are necessary to clarify the extent of the influence of physicochemical variations on the plastic additive migration and whether these conditions may produce cumulative or interactive effects of leachates on freshwater species and ecosystems. 


\section{Research gaps and future perspectives}

The efforts recently expended in the chemical and toxicological characterization of plastic leachates provided new insights into the possible impacts of synthetic material on aquatic ecosystems, so far mainly focused on the sole physical effects of MP ingestion or waterborne pollutant adsorption. Experimental studies described herein confirm that rate, amount, and composition of additives released from plastics may depend on several factors, including the intensity of weathering forces, the texture (amorphous/crystalline) of polymers, the type and strength of polymer-additive bonds and the physicochemical properties of additives themselves.

Overall, numerous gaps hinder a comprehensive hazard and risk assessment of plastic products. Information on additives used for the production of a given plastic article are generally not accessible. Plastics contain a wide array of known substances, but also a number of non-intentionally added substances (NIAS) that represent compounds not yet completely identified. Nevertheless, they are important when evaluating strategies for recycling or substitution for safer items. It is essential to assess the chemical composition of plastics items; however, methodologies for plastic leachate preparation greatly differ: consequently, results from different laboratories cannot be compared. It might be expected that all plastic additives end up in the environment, but in different relative amounts than given in the original product composition. Also, their composition may change depending on the aquatic environment, e.g. salinity or $\mathrm{pH}$ leading to an environmental mixture which is qualitatively different from that obtained by theoretical calculation. Therefore, whole leachate testing represents a useful option for risk assessment.

Toxicological evidence indicates that the exposure to mixtures of chemicals leached from plastics induced adverse effects: from alterations of algal growth and photosynthetic processes to the impairments of embryonic development, behaviour, motility and/or survival in fish and invertebrates. It is often noted that detrimental effects occur also after exposure to diluted leachates; however, although they stress the potential harmfulness of plastic leachates, data reported as leachate \% dilution are per se not meaningful, unless supported by precise description of leachate preparation. Thus, information on leachate composition accompanying ecotoxicity studies is advisable. In fact, in many toxicity studies model organisms are exposed to leachates of unknown or partially known composition. Knowledge on the additives released by plastic items is crucial to relate the overall effect to specific compounds in the mixtures and compare/integrate data. Future studies should be addressed to the implementation and standardization of non-target methods for the chemical screening of plastic leachates, and to identify all components and eventual relationships with the effects observed in biota. Synergistic and antagonistic effects of chemicals composing the leachate also need to be further investigated to understand the cumulative impacts on living species. Moreover, since additives from plastic debris may be metabolized and transformed by biofilm-forming microorganisms in natural environment, future studies should integrate the screening of conventional additives with the measurement of bio-transformed or biodegraded by-products.

In addition to single chemicals intentionally used in plastic item manufacture, the mixture toxicity of the overall leachate should be determined for a relevant set of effects (e.g. genotoxicity, endocrine disruption). Novel approaches, where in vitro toxicity testing is combined with chemical analysis, or semi-quantitative assessments, where chemicals with assumed highest exposure levels are identified, can be useful for this purpose. The focus of the toxicity tests would then shift from assessing individual substances to accounting for mixture toxicity. For this purpose, the importance of guidelines for the preparation of leachates and a set of sensitive biological tests are obvious. Among these, tests on invertebrate embryos (e.g. Capolupo et al., 2020) could be useful because they fulfil the requirements of high through- put screening assays with the capacity to deliver data quickly, precisely, reliably, and with high sensitivity.

Further insights on the possibility of additive release from ingested plastics by action of digestive fluids are advisable. The threat to the ingesting organism is even more pronounced if the additives are endocrine disruptor chemicals. Very low dosages of these chemicals, well below their accepted conventional toxicity levels, can interfere with animal physiology resulting in long-term adverse effects (Andrady and Rajapakse, 2019; Koelmans et al., 2014; Khan et al., 2017; Tanaka et al., 2020). Although digestive processes are different in fish and birds, relative to mammals, possible implication for human health cannot be ruled out. Plastics additives of concern to human health include phthalates, BPA, brominated flame retardants, triclosan, bisphenone and organotin (Galloway, 2015) but, to the best of our knowledge, none was investigated regarding the leaching into human tissues directly.

Compounds simultaneously present in the leachates may interfere with cell regulatory pathways at low concentrations. It appears that for aquatic organisms no data is available to identify targets (i.e. receptors; membrane) and mechanisms (i.e. signalling pathways; effector molecules) that help to predict chemical impacts on individuals and populations. Once these become available, they would define adverse outcome pathways (AOP) to support chemical risk assessments (Ankley et al., 2010). Only one investigation is reported regarding the effects of leachates on signalling pathways, which was carried out on mammalian cells (Rummel et al., 2019). Targets included aryl hydrocarbon receptor (AhR)-dependent metabolic enzymes, peroxisome proliferator-activated receptor (PPAR $\gamma$ )-dependent pathways, endocrine effects mediated by binding to Estrogen Receptor $\alpha$ (ER $\alpha$ ), adaptive response to oxidative stress (AREc32) (Table S1). As a common response, plastic leachates from PE, PET, PP, PS exposed to UV treatment challenged the oxidative stress pathway; leachates from PE also activated PPAR $\gamma$-dependent pathways in exposed cells. These data put into evidence the extent to which plastic leachates may interfere with cellular regulations. Although largely unexplored from a comparative perspective, most of the key molecular components implicated in the mechanism of action of different compounds likely appeared early in animal evolution. It is not surprising that the effects of toxic compounds observed in different animal taxonomic groups stem from their interactions with conserved molecular pathways. Some efforts are needed to look for initiating events in leachate toxicity. From examining biochemical effects induced by MPs (Jeong and Choi, 2019) and the few data available on leachates (Trestrail et al., 2020), we may speculate that oxidative stress is a shared pathway. Therefore, it is suggested as one of the targets of future studies on the effect of plastic leachates.

Interventions should be undertaken at national and international levels to restrict the use of single additives found to trigger detrimental effects on ecosystems. We may want to consider, for example, that current regulatory frameworks on surface water quality are not even conclusive for BPA, which is likely the most studied EDCs and is known for its widespread occurrence in aquatic systems and ecotoxicity. A great effort is required to agree on methodologies, experimental trials, and data sharing. A major challenge is the need for establishing common criteria and regulatory frameworks for assessing the cumulative risk of additive mixtures leached by plastics in aquatic environment. The REACH-CLP and BRP regulations introduced component-based, bridging and read-across methods for mixture risk assessment applicable when composition, concentration, and toxicity data are known for all dissolved chemicals (1272/2008/EC; 1907/2006/EC; Posthuma et al., 2019). Adopting these methods for estimating the risk posed by the additive plastic leaching can be very challenging, as these require information often kept confidential by producers, or unknown in the case of beach-collected MPs. In this respect, increasing our understanding of the chemical composition and effects of plastic leachates would represent a significant step forward towards the identification of low-im- 
pact plastic formulation and for establishing reliable safety threshold for plastic additives co-occurring in aquatic ecosystems.

$$
,,,,,,,
$$

\section{Declaration of Competing Interest}

The authors declare that they have no known competing financial interests or personal relationships that could have appeared to influence the work reported in this paper.

\section{Acknowledgements}

This work was conducted under the framework of the Joint Programming Initiative - Healthy and Productive Seas and Oceans (JPI-Oceans) as part of the European project PLASTOX (Direct and indirect ecotoxicological impacts of microplastics on marine organisms), grant agreement $\mathrm{N}^{\circ} 495696324$ (http://www.jpi-oceans.eu/plastox). The work has been directly funded by the MIUR-Italian Ministry of Education, University and Research (protocol N $\left.{ }^{\circ} 696231 / 03 / 2015\right)$. GK was supported by a grant funded by the European Commission under the Erasmus Mundus Master Degree Programme in Water and Coastal Management (WACOMA; Project nr 586596-EPP-1-2017-1-IT-EPPKA1-JMD-MOB).

\section{Supplementary materials}

Supplementary material associated with this article can be found, in the online version, at doi:10.1016/j.watres.2020.116170.

\section{Bibliography}

Aarab, N, Lemaire-Gony, S, Unruh, E, Hansen, P D, Larsen, B K, Andersen, O K, Narbonne, J F, 2006. Preliminary study of responses in mussel (Mytilus edilus) exposed to bisphenol A, diallyl phthalate and tetrabromodiphenyl ether. Aquat. Toxicol. 78, 86-92. https://doi.org/10.1016/j.aquatox.2006.02.021.

Agamuthu, P, Mehran, S, Norkhairah, A, Norkhairiyah, A, 2019. Marine debris: a review of impacts and global initiatives. Waste Manag. Res. 37, 987-1002. https://doi.org/ 10.1177/0734242X19845041.

Andrady, A L, Neal, M A, 2009. Applications and societal benefits of plastics. Phil. Trans. R. Soc. B 364, 1977-1984. https://doi.org/10.1098/rstb.2008.0304.

Andrady, A L, Rajapakse, N, 2019. Additives and chemicals in plastics. Hazardous Chemicals Associated with Plastics in the Marine Environment. Springer, pp. 1-17. https://doi.org/10.1007/978-3-319-95568-1.

Ankley, G T, Bennett, R S, Erickson, R J, Hoff, D J, Hornung, M W, Johnson, R D, Mount, D R, Nichols, J W, Russom, C L, Schmieder, P K, Serrrano, J A, Tietge, J E, Villeneuve, D L, 2010. Adverse outcome pathways: a conceptual framework to support ecotoxicology research and risk assessment. Environ. Toxicol. Chem. 29, 730-741. https://doi.org/10.1002/etc.34.

Ashton, K, Holmes, L, Turner, A, 2010. Association of metals with plastic production pellets in the marine environment. Mar. Pollut. Bull. 60, 2050-2055. https://doi.org/ 10.1016/j.marpolbul.2010.07.014.

ASTM, 2020. Test Method for Determining the Aerobic Degradation and Anaerobic Biodegradation of Plastic Materials under Accelerated Bioreactor Landfill Conditions. ASTM International. https://doi.org/10.1520/D7475-20.

ASTM, 2012. Guide for Conducting Static Acute Toxicity Tests Starting with Embryos of Four Species of Saltwater Bivalve Molluscs. ASTM International. https://doi.org/10 1520/E0724-98R12.

Azam, F, Fenchel, T, Field, J G, Gray, J S, Meyer-Reil, L A, Thingstad, F, 1983. The ecological role of water-column microbes in the sea. Mar. Ecol. Progr. Ser. 10, 257-263. https://doi.org/10.3354/meps010257.

Azam, F, Fenchel, T, Field, J G, Gray, J S, Meyer-Reil, L A, Thingstad, F, 1983. The ecological role of water-column microbes in the sea. Mar. Ecol. Progr. Ser.. https:// doi.org/10.3354/meps010257.

Balbi, T, Franzellitti, S, Fabbri, R, Montagna, M, Fabbri, E, Canesi, L, 2016. Impact of bisphenol A (BPA) on early embryo development in the marine mussel Mytilu galloprovincialis: effects on gene transcription. Environ. Pollut. 218, 996-1004. https: //doi.org/10.1016/j.envpol.2016.08.050.

Baršienè, J, Šyvokienè, J, Bjornstad, A, 2006. Induction of micronuclei and other nuclear abnormalities in mussels exposed to bisphenol A, diallyl phthalate and tetrabromodiphenyl ether-47. Aquat. Toxicol. 78, 105-108. https://doi.org/10.1016/ j.aquatox.2006.02.023.

Basheer, C, Lee, H K, Tan, K S, 2004. Endocrine disrupting alkylphenols and bisphenol-A in coastal waters and supermarket seafood from Singapore. Mar. Pollut. Bull. 48, 1161-1167. https://doi.org/10.1016/j.marpolbul.2004.04.009.
Bejgarn, S, MacLeod, M, Bogdal, C, Breitholtz, M, 2015. Toxicity of leachate from weathering plastics: an exploratory screening study with Nitocra spinipes. Chemosphere 132, 114-119. https://doi.org/10.1016/j.chemosphere.2015.03.010.

Berens, A R, 1997. Predicting the migration of endocrine disrupters from rigid plastics. Polym. Eng. Sci. 37, 391-395. https://doi.org/10.1002/pen.11681.

Bollmann, U E, Möller, A, Xie, Z, Ebinghaus, R, Einax, J W, 2012. Occurrence and fate of organophosphorus flame retardants and plasticizers in coastal and marine surface waters. Water Res. 46, 531-538. https://doi.org/10.1016/j.watres.2011.11.028.

Boyle, D, Catarino, A I, Clark, N J, Henry, T B, 2020. Polyvinyl chloride (PVC) plastic fragments release $\mathrm{Pb}$ additives that are bioavailable in zebrafish. Environ. Pollut. 263, 114422. https://doi.org/10.1016/j.envpol.2020.114422.

Browne, M A, Niven, S J, Galloway, T S, Rowland, S J, Thompson, R C, 2013. Microplastic Moves Pollutants and Additives to Worms, Reducing Functions Linked to Health and Biodiversity. Curr. Biol. 23, 2388-2392. https://doi.org/10.1016/j.cub.2013.10.012.

Brydson, J A, 1999. Plastics Materials. seventh ed Butterworth-Heinemann, Oxford; Boston, p. 920 ISBN: 9780750641326.

Canesi, L, Betti, M, Lorusso, L C, Ciacci, C, Gallo, G, 2005. 'In vivo' effects of Bisphenol A in Mytilus hemocytes: modulation of kinase-mediated signalling pathways. Aquat. Toxicol. 71, 73-84. https://doi.org/10.1016/j.aquatox.2004.10.011.

Canesi, L, Borghi, C, Ciacci, C, Fabbri, R, Vergani, L, Gallo, G, 2007. Bisphenol-A alters gene expression and functional parameters in molluscan hepatopancreas. Mol. Cell. Endocrinol. 276, 36-44. https://doi.org/10.1016/j.mce.2007.06.002.

Canesi, L, Fabbri, E, 2015. Environmental effects of BPA: focus on aquatic species. Dose-Response 13, 155932581559830. https://doi.org/10.1177/1559325815598304.

Canesi, L, Lorusso, L C, Ciacci, C, Betti, M, Rocchi, M, Pojana, G, Marcomini, A, 2007. Immunomodulation of Mytilus hemocytes by individual estrogenic chemicals and environmentally relevant mixtures of estrogens: in vitro and in vivo studies. Aquat. Toxicol. 81, 36-44. https://doi.org/10.1016/j.aquatox.2006.10.010.

Capolupo, M, Sørensen, L, Jayasena, K D R, Booth, A M, Fabbri, E, 2020. Chemical composition and ecotoxicity of plastic and car tire rubber leachates to aquatic organisms. Water Res. 169, 115270. https://doi.org/10.1016/j.watres.2019.115270.

Chae, Y, Hong, S H, An, Y-J, 2020. Photosynthesis enhancement in four marine microalgal species exposed to expanded polystyrene leachate. Ecotox. Environ. Safe 189, 109936. https://doi.org/10.1016/j.ecoenv.2019.109936.

ECHA, 2018. Plastic Additives Initiative. Available at. https://echa.europa.eu/plasticadditives-initiative accessed on March 5th, 2020).

European Council Decision, 2009. Directive 2002/95/EC- Electrical and Electronic Equipment - Restriction of Use of Certain Hazardous Substances - Decabromodiphenyl Ether ("DecaBDE") Available at. https://eur-lex.europa.eu/legal-content/EN/TXT/ ?uri $=$ CELEX\%3A62006CJ0014 (accessed on March 30th, 2020).

European Food Safety Authority (EFSA), 2011. Scientific opinion on hexabromocyclododecanes (HBCDDs) in food. EFSA J. 9, 2296. https://doi.org/10. 2903/j.efsa.2011.2296.

Fossi, M C, Panti, C, Guerranti, C, Coppola, D, Giannetti, M, Marsili, L, Minutoli, R, 2012. Are baleen whales exposed to the threat of microplastics? A case study of the Mediterranean fin whale (Balaenoptera physalus). Mar. Pollut. Bull. 64, 2374-2379. https://doi.org/10.1016/j.marpolbul.2012.08.013.

Franzellitti, S, Canesi, L, Auguste, M, Wathsala, R H G R, Fabbri, E, 2019. Microplastic exposure and effects in aquatic organisms: a physiological perspective. Environ. Toxicol. Phar. 68, 37-51. https://doi.org/10.1016/j.etap.2019.03.009.

Fu, M, Li, Z, Gao, H, 2007. Distribution characteristics of nonylphenol in Jiaozhou Bay of Qingdao and its adjacent rivers. Chemosphere 69, 1009-1016. https://doi.org/10. 1016/j.chemosphere.2007.04.061.

Galgani, F, Hanke, G, Maes, T, 2015. Global distribution, composition and abundance of marine litter. In: Bergmann, M, Gutow, L, Klages, M (Eds.), Marine Anthropogenic Litter. Springer International Publishing, Cham, pp. 29-56. https://doi.org/10.1007/ 978-3-319-16510-3_2

Gallo, F, Fossi, C, Weber, R, Santillo, D, Sousa, J, Ingram, I, Nadal, A, Romano, D, 2018. Marine litter plastics and microplastics and their toxic chemicals components: the need for urgent preventive measures. Environ. Sci. Eur. 30, 13. https://doi.org/10. 1186/s12302-018-0139-z.

Galloway, T S, Cole, M, Lewis, C, 2017. Interactions of microplastic debris throughout the marine ecosystem. Nat. Ecol. Evol. 1, 1-8. https://doi.org/10.1038/s41559-017-0116.

Galloway, T S, Lewis, C N, 2016. Marine microplastics spell big problems for future generations. Proc. Natl. Acad. Sci. USA 113, 2331. https://doi.org/10.1073/pnas. 1600715113.

Galloway, T S, 2015. Micro- and nano-plastics and human health. In: Bergmann, M, Gutow, L, Klages, M (Eds.), Marine Anthropogenic Litter. Springer International Publishing, Cham, pp. 343-366. https://doi.org/10.1007/978-3-319-16510-313.

Gandara e Silva, P P, Nobre, C R, Resaffe, P, Pereira, C D S, Gusmão, F, 2016. Leachate from microplastics impairs larval development in brown mussels. Water Res. 106, 364-370. https://doi.org/10.1016/j.watres.2016.10.016.

GESAMP, 2016. Sources, fate and effects of microplastics in the marine environment: part two of a global assessment. In: Kershaw, P J, Rochman, C M (Eds.), IMO/FAO/ UNESCO IOC/UNIDO/WMO/IAEA/UN/UNEP/UNDP Joint Group of Experts on the Scientific Aspects of Marine Environmental Protection). Rep. Stud. GESAMP No. 93. p. 220.

Gewert, B, Plassmann, M M, MacLeod, M, 2015. Pathways for degradation of plastic polymers floating in the marine environment. Environ. Sci. Proc. Imp. 17, 1513-1521. https://doi.org/10.1039/c5em00207a.

González-Soto, N, Hatfield, J, Katsumiti, A, Duroudier, N, Lacave, J M, Bilbao, E, Orbea, A, Navarro, E, Cajaraville, M P, 2019. Impacts of dietary exposure to different sized polystyrene microplastics alone and with sorbed benzo[a]pyrene on biomarkers 
and whole organism responses in mussels Mytilus galloprovincialis. Sci. Tot. Environ. 684, 548-566. https://doi.org/10.1016/j.scitotenv.2019.05.161.

Groh, K J, Backhaus, T, Carney-Almroth, B, Geueke, B, Inostroza, P A, Lennquist, A, Leslie, H A, Maffini, M, Slunge, D, Trasande, L, Warhurst, A M, Muncke, J, 2019. Overview of known plastic packaging-associated chemicals and their hazards. Sci. Total Environ. 651, 3253-3268. https://doi.org/10.1016/j.scitotenv.2018.10.015.

Gu, S-Y, Ekpeghere, K I, Kim, H-Y, Lee, I-S, Kim, D-H, Choo, G, Oh, J-E, 2017. Brominated flame retardants in marine environment focused on aquaculture area: occurrence, source and bioaccumulation. Sci. Total Environ. 601-602, 1182-1191. https://doi. org/10.1016/j.scitotenv.2017.05.209.

Hahladakis, J N, Velis, C A, Weber, R, Iacovidou, E, Purnell, P, 2018. An overview of chemical additives presents in plastics: migration, release, fate and environmental impact during their use, disposal and recycling. J. Hazar. Mater. 344, 179-199. https: //doi.org/10.1016/j.jhazmat.2017.10.014.

Hamlin, H J, Marciano, K, Downs, C A, 2015. Migration of nonylphenol from food-grade plastic is toxic to the coral reef fish species Pseudochromis fridmani. Chemosphere 139, 223-228. https://doi.org/10.1016/j.chemosphere.2015.06.032.

Hansen, E, Nilsson, N, Lithner, D, Lassen, C, 2013. Hazardous Substances in Plastic Materials - Miljødirektoratet. Miljødirektoratet/Norwegian Environment Agency Available at. https://www.miljodirektoratet.no/publikasjoner/publikasjoner-fra-klif/ 2013/februar/hazardous-substances-in-plastic-materials/ (accessed on March 29th 2020).

Hermabessiere, L, Dehaut, A, Paul-Pont, I, Lacroix, C, Jezequel, R, Soudant, P, Duflos, G, 2017. Occurrence and effects of plastic additives on marine environments and organisms: a review. Chemosphere 182, 781-793. https://doi.org/10.1016/j. chemosphere.2017.05.096.

Hernandez, L M, Xu, E G, Larsson, H C E, Tahara, R, Maisuria, V B, Tufenkji, N, 2019. Plastic teabags release billions of microparticles and nanoparticles into tea. Environ. Sci. Technol. 53, 12300-12310. https://doi.org/10.1021/acs.est.9b02540.

Herzke, D, Anker-Nilssen, T, Nøst, T H, Götsch, A, Christensen-Dalsgaard, S, Langset, M, Fangel, K, Koelmans, A A, 2016. Negligible impact of ingested microplastics on tissue concentrations of persistent organic pollutants in northern fulmars off Coastal Norway. Environ. Sci. Technol. 50, 1924-1933. https://doi.org/10.1021/acs. est.5b04663.

Hidalgo-Ruz, V, Gutow, L, Thompson, R C, Thiel, M, 2012. Microplastics in the marine environment: a review of the methods used for identification and quantification. Environ. Sci. Technol. 46, 3060-3075. https://doi.org/10.1021/es2031505.

Hirai, H, Takada, H, Ogata, Y, Yamashita, R, Mizukawa, K, Saha, M, Kwan, C, Moore, C, Gray, H, Laursen, D, Zettler, E R, Farrington, J W, Reddy, C M, Peacock, E E, Ward, M W, 2011. Organic micropollutants in marine plastics debris from the open ocean and remote and urban beaches. Mar. Pollut. Bull. 62, 1683-1692. https://doi.org/10. 1016/j.marpolbul.2011.06.004.

Hong, S H, Shim, W J, Jang, M, 2018. Chapter 9 - Chemicals associated with marine plastic debris and microplastics: analyses and contaminant levels. In: Zeng, E Y (Ed.), Microplastic Contamination in Aquatic Environments. Elsevier, pp. 271-315. https:// doi.org/10.1016/B978-0-12-813747-5.00009-6.

Ioakeimidis, C, Galgani, F, Papatheodorou, G, 2019. Occurrence of marine litter in the marine environment: a world panorama of floating and seafloor plastics. In: Takada, H, Karapanagioti, H K (Eds.), Hazardous Chemicals Associated with Plastics in the Marine Environment, The Handbook of Environmental Chemistry. Springer International Publishing, Cham, pp. 93-120. https://doi.org/10.1007/698_2017_22.

Jang, M, Shim, W J, Han, G M, Rani, M, Song, Y K, Hong, S H, 2017. Widespread detection of a brominated flame retardant, hexabromocyclododecane, in expanded polystyrene marine debris and microplastics from South Korea and the Asia-Pacific coastal region. Environ. Pollut. 231, 785-794. https://doi.org/10.1016/j.envpol.2017.08.066.

Jeong, J, Choi, J, 2019. Adverse outcome pathways potentially related to hazard identification of microplastics based on toxicity mechanisms. Chemosphere 231, 249-255. https://doi.org/10.1016/j.chemosphere.2019.05.003.

Käppler, A, Fischer, D, Oberbeckmann, S, Schernewski, G, Labrenz, M, Eichhorn, K-J, Voit, B, 2016. Analysis of environmental microplastics by vibrational microspectroscopy: FTIR, Raman or both? Anal. Bioanal. Chem. 408, 8377-8391. https://doi.org/10. 1007/s00216-016-9956-3.

Ke, A-Y, Chen, J, Zhu, J, Wang, Y-H, Hu, Y, Fan, Z-L, Chen, M, Peng, P, Jiang, S-W, Xu, $\mathrm{X}-\mathrm{R}, \mathrm{Li}, \mathrm{H}-\mathrm{X}, 2019$. Impacts of leachates from single-use polyethylene plastic bags on the early development of clam Meretrix meretrix (Bivalvia: Veneridae). Mar. Pollut. Bull. 142, 54-57. https://doi.org/10.1016/j.marpolbul.2019.03.029.

Khan, F R, Boyle, D, Chang, E, Bury, N R, 2017. Do polyethylene microplastic beads alter the intestinal uptake of $\mathrm{Ag}$ in rainbow trout (Oncorhynchus mykiss)? Analysis of the MP vector effect using in vitro gut sacs. Environ. Pollut. 231, 200-206. https://doi.org/ 10.1016/j.envpol.2017.08.019.

Kim, E-J, Kim, J-W, Lee, S-K, 2002. Inhibition of oocyte development in Japanese medaka (Oryzias latipes) exposed to di-2-ethylhexyl phthalate. Environ. Int. 28, 359-365. https: //doi.org/10.1016/S0160-4120(02)00058-2.

Kocasoy, G, Murat, Z M, 2009. Comparison of the characteristics of the leachate and the eluates obtained by different methods. J. Environ. Sci. Health A 44, 605-614. https:// doi.org/10.1080/10934520902784666.

Koelmans, A A, Besseling, E, Foekema, E M, 2014. Leaching of plastic additives to marine organisms. Environ. Pollut. 187, 49-54. https://doi.org/10.1016/j.envpol.2013.12. 013.

Kwan, C S, Takada, H, 2016. Release of additives and monomers from plastic wastes. In: Takada, H, Karapanagioti, H K (Eds.), Hazardous Chemicals Associated with Plastics in the Marine Environment. Springer International Publishing, Cham, pp. 51-70. https: //doi.org/10.1007/698_2016 122.

Li, H-X, Getzinger, G J, Ferguson, P L, Orihuela, B, Zhu, M, Rittschof, D, 2016. Effects of toxic leachate from commercial plastics on larval survival and settlement of the barnacle Amphibalanus amphitrite. Environ. Sci. Technol. 50, 924-931. https://doi.org/ 10.1021/acs.est.5b02781.

Lindeque, P K, Cole, M, Coppock, R L, Lewis, C N, Miller, R Z, Watts, A J R, Wilson-McNeal, A, Wright, S L, Galloway, T S, 2020. Are we underestimating microplastic abundance in the marine environment? A comparison of microplastic capture with nets of different mesh-size. Environ. Pollut. 114721. https://doi.org/10. 1016/j.envpol.2020.114721.

Lithner, D, Damberg, J, Dave, G, Larsson, Å, 2009. Leachates from plastic consumer products - screening for toxicity with Daphnia magna. Chemosphere 74, 1195-1200. https://doi.org/10.1016/j.chemosphere.2008.11.022.

Lithner, D, Nordensvan, I, Dave, G, 2012. Comparative acute toxicity of leachates from plastic products made of polypropylene, polyethylene, PVC, acrylonitrile-butadiene-styrene, and epoxy to Daphnia magna. Environ. Sci. Pollut. Res. 19, 1763-1772. https://doi.org/10.1007/s11356-011-0663-5.

Luo, H, Xiang, Y, He, D, Li, Y, Zhao, Y, Wang, S, Pan, X, 2019. Leaching behavior of fluorescent additives from microplastics and the toxicity of leachate to Chlorella vulgaris. Sci. Total Environ. 678, 1-9. https://doi.org/10.1016/j.scitotenv.2019.04. 401.

Mayer, P, Vaes, W H J, Hermens, J L M, 2000. Absorption of hydrophobic compounds into the poly(dimethylsiloxane) coating of solid-phase microextraction fibers: high partition coefficients and fluorescence microscopy images. Anal. Chem. 72, 459-464. https://doi.org/10.1021/ac990948f.

Menicagli, V, Balestri, E, Lardicci, C, 2019. Exposure of coastal dune vegetation to plastic bag leachates: a neglected impact of plastic litter. Sci. Total Environ. 683, 737-748. https://doi.org/10.1016/j.scitotenv.2019.05.245.

Murphy, J, 2001. Additives for Plastics Handbook. Elsevier, pp. 5-269 ISBN 978-0-08-049861-4.

Nakashima, E, Isobe, A, Kako, S, Itai, T, Takahashi, S, 2012. Quantification of toxic metals derived from macroplastic litter on Ookushi Beach, Japan. Environ. Sci. Technol 46, 10099-10105. https://doi.org/10.1021/es301362g.

Napper, I E, Thompson, R C, 2019. Chapter 22 - Marine plastic pollution: other than microplastic. In: Letcher, T M, Vallero, D A (Eds.), Waste, second ed. Academic Press, pp. 425-442. https://doi.org/10.1016/B978-0-12-815060-3.00022-0.

OECD, 1992. Test No. 203: Fish, Acute Toxicity Test, OECD Guidelines for the Testing of Chemicals, Section 2. OECD. https://doi.org/10.1787/9789264069961-en.

OECD, 1998. Test No. 212: Fish, Short-term Toxicity Test on Embryo and Sac-Fry Stages, OECD Guidelines for the Testing of Chemicals, Section 2. OECD. https://doi.org/10. 1787/9789264070141-en.

OECD, 2004. Test No. 202: Daphnia sp. Acute Immobilisation Test, OECD Guidelines for the Testing of Chemicals, Section 2. OECD. https://doi.org/10.1787/9789264069947 en.

Oliviero, M, Tato, T, Schiavo, S, Fernández, V, Manzo, S, Beiras, R, 2019. Leachates of micronized plastic toys provoke embryotoxic effects upon sea urchin Paracentrotus lividus. Environ. Pollut. 247, 706-715. https://doi.org/10.1016/j.envpol.2019.01.098.

Orbea, A, Ortiz-Zarragoitia, M, Cajaraville, M P, 2002. Interactive effects of benzopyrene and cadmium and effects of di(2-ethylhexyl) phthalate on antioxidant and peroxisomal enzymes and peroxisomal volume density in the digestive gland of mussel Mytilus galloprovincialis. Biomarkers 7, 33-48. https://doi.org/10.1080/ 13547500110066119.

Park, S Y, Choi, J, 2007. Cytotoxicity, genotoxicity and ecotoxicity assay using human cell and environmental species for the screening of the risk from pollutant exposure. Environ. Int. 33, 817-822. https://doi.org/10.1016/j.envint.2007.03.014.

PlasticEurope, 2017. An Analysis of European Plastics Production, Demand and Waste Data. p. 44 Available at. https://www.plasticseurope.org/application/files/5715/ $1717 / 4180 /$ Plastics the facts 2017 FINAL for website one page.pdf pp.

Posthuma, L, Altenburger, R, Backhaus, T, Kortenkamp, A, Müller, C, Focks, A, ZwartDe, D, Brack, W, 2019. Improved component - based methods for mixture risk assessment are key to characterize complex chemical pollution in surface waters. Environ. Sci. Eur. 31, 70. https://doi.org/10.1186/s12302-019-0246-5.

Ribeiro, F, O'Brien, J W, Galloway, T, Thomas, K V, 2019. Accumulation and fate of nanoand micro-plastics and associated contaminants in organisms. Trend. Anal. Chem. 111, 139-147. https://doi.org/10.1016/j.trac.2018.12.010.

Romera-Castillo, C, Maria, P, Langer, T M, Álvarez-Salgado, X A, Herndl, G J, 2018 Dissolved organic carbon leaching from plastics stimulates microbial activity in the ocean. Nat. Commun. 9, 1430. http://doi.org/10.1038/s41467-018-03798-5.

Rummel, C D, Escher, B I, Sandblom, O, Plassmann, M M, Arp, H P H, MacLeod, M, Jahnke, A, 2019. Effects of leachates from UV-weathered microplastic in cell-based bioassays. Environ. Sci. Technol. 53, 9214-9223. https://doi.org/10.1021/acs.est. 9b02400.

Ryan, P G, 2019. Ingestion of plastics by marine organisms. In: Takada, H, Karapanagioti, H K (Eds.), Hazardous Chemicals Associated with Plastics in the Marine Environment, The Handbook of Environmental Chemistry. Springer International Publishing, Cham, pp. 235-266. https://doi.org/10.1007/698_2016_21.

Sajiki, J, Yonekubo, J, 2003. Leaching of Bisphenol A (BPA) to seawater from polycarbonate plastic and its degradation by reactive oxygen species. Chemosphere 51, 55-62. https://doi.org/10.1016/S0045-6535(02)00789-0.

Sánchez-Avila, J, Tauler, R, Lacorte, S, 2012. Organic micropollutants in coastal waters from NW Mediterranean Sea: aources distribution and potential risk. Environ. Int. 46, 50-62. https://doi.org/10.1016/j.envint.2012.04.013.

Schiavo, S, Oliviero, M, Chiavarini, S, Manzo, S, 2020. Adverse effects of oxo-degradable plastic leachates in freshwater environment. Environ. Sci. Pollut. Res. 27, 8586-8595. https://doi.org/10.1007/s11356-019-07466-z.

Schiavo, S, Oliviero, M, Romano, V, Dumontet, S, Manzo, S, Liu, G, 2018. Ecotoxicological assessment of virgin plastic pellet leachates in freshwater matrices. J. Environ. Account. Manag. 6, 345-353. https://doi.org/10.5890/JEAM.2018.12.007. 
Schmidt, N, Castro-Jiménez, J, Fauvelle, V, Ourgaud, M, Sempéré, R, 2020. Occurrence of organic plastic additives in surface waters of the Rhône River (France). Environ Pollut. 257, 113637. https://doi.org/10.1016/j.envpol.2019.113637.

Schrank, I, Trotter, B, Dummert, J, Scholz-b, B M, Laforsch, C, Martin, G J L, 2019. Effects of microplastic particles and leaching additive on the life history and morphology of Daphnia magna Environ. Pollut., 255. doi:10.1016/j.envpol.2019.113233.

Seuront, L, 2018. Microplastic leachates impair behavioural vigilance and predator avoidance in a temperate intertidal gastropod. Biol. Lett. 14, 20180453. https://doi. org/10.1098/rsbl.2018.0453.

Sheftel, V O, 2000. Indirect food additives and polymers: migration and toxicology. Food Science and Technology. CRC Press, p. 1320. https://doi.org/10.1201/ 9781482293821.

Shim, W J, Hong, S H, Eo, S E, 2017. Identification methods in microplastic analysis: a review. Anal. Methods 9, 1384-1391. https://doi.org/10.1039/C6AY02558G.

Sjollema, S B, Redondo-Hasselerharm, P, Leslie, H A, Kraak, M H S, Vethaak, A D, 2016 Do plastic particles affect microalgal photosynthesis and growth? Aquat. Toxicol 170, 259-261. https://doi.org/10.1016/j.aquatox.2015.12.002.

SOR/2008-218 Government of Canada, 2020. Polybrominated Diphenyl Ethers Regukation Available at. https://laws-lois.justice.gc.ca/eng/regulations/SOR-2008218/FullText.html accessed on March 29th.

Staples, C A, Peterson, D R, Parkerton, T F, Adams, W J, 1997. The environmental fate of phthalate esters: a literature review. Chemosphere 35, 667-749. https://doi.org/10. 1016/S0045-6535(97)00195-1

Stockholm Convention, 2016. Listing of POPs in the Stockholm Convention Available at. http://chm.pops.int/TheConvention/ThePOPs/ListingofPOPs/tabid/2509/Default. aspx (accessed on March 5th, 2020).

Tagatz, M E, Plaia, G R, Deans, C H, 1986. Toxicity of dibutyl phthalate-contaminated sediment to laboratory- and field-colonized estuarine benthic communities. Bull. Environ. Contam. Toxicol. 37, 141-150.

Tanaka, K, Takada, H, Yamashita, R, Mizukawa, K, Fukuwaka, M, Watanuki, Y, 2015 Facilitated leaching of additive-derived PBDEs from plastic by seabirds' stomach oil and accumulation in tissues. Environ. Sci. Technol. 49, 11799-11807. https://doi.org/ 10.1021/acs.est.5b01376.

Tanaka, K, Takada, H, Yamashita, R, Mizukawa, K, Fukuwaka, M, Watanuki, Y, 2013. Accumulation of plastic-derived chemicals in tissues of seabirds ingesting marine plastics. Mar. Pollut. Bull. 69, 219-222. https://doi.org/10.1016/j.marpolbul.2012. 12.010 .

Tanaka, K, Watanuki, Y, Takada, H, Ishizuka, M, Yamashita, R, Kazama, M, Hiki, N, Kashiwada, F, Mizukawa, K, Mizukawa, H, Hyrenbach, D, Hester, M, Ikenaka, Y, Nakayama, S M M, 2020. In Vivo accumulation of plastic-derived chemicals into seabird tissues. Curr. Biol. 30, 723-728.e3. https://doi.org/10.1016/j.cub.2019.12. 037.

Taniguchi, S, Colabuono, F I, Dias, P S, Oliveira, R, Fisner, M, Turra, A, Izar, G M, Abessa, D M S, Saha, M, Hosoda, J, Yamashita, R, Takada, H, Lourenço, R A, Magalhães, C A, Bícego, M C, Montone, R C, 2016. Spatial variability in persistent organic pollutants and polycyclic aromatic hydrocarbons found in beach-stranded pellets along the coast of the state of São Paulo, South-eastern Brazil. Mar. Pollut. Bull. 106, 87-94. https:// doi.org/10.1016/j.marpolbul.2016.03.024.

Tetu, S G, Sarker, I, Schrameyer, V, Pickford, R, Elbourne, L D H, Moore, L R, Paulsen, I T, 2019. Plastic leachates impair growth and oxygen production in Prochlorococcus, the ocean's most abundant photosynthetic bacteria. Commun. Biol 2, 1-9. https://doi. org $/ 10.1038 / \mathrm{s} 42003-019-0410-x$.

Teuten, E L, Saquing, J M, Knappe, D R U, Barlaz, M A, Jonsson, S, Björn, A, Rowland, S J, Thompson, R C, Galloway, T S, Yamashita, R, Ochi, D, Watanuki, Y, Moore, C, Viet, P H, Tana, T S, Prudente, M, Boonyatumanond, R, Zakaria, M P, Akkhavong, K, Ogata, Y, Hirai, H, Iwasa, S, Mizukawa, K, Hagino, Y, Imamura, A, Saha, M, Takada, H, 2009. Transport and release of chemicals from plastics to the environment and to wildlife. Philos. Trans. R. Soc. B. 364, 2027-2045. https://doi.org/10.1098/rstb.2008.0284.

Thaysen, C, Stevack, K, Ruffolo, R, Poirier, D, De Frond, H, DeVera, J, Sheng, G, Rochman $\mathrm{C} M, 2018$. Leachate from expanded polystyrene cups is toxic to aquatic invertebrates (Ceriodaphnia dubia). Front. Mar. Sci 5, 71. https://doi.org/10.3389/fmars.2018. 00071.

Thibaut, R, Porte, C, 2004. Effects of endocrine disrupters on sex steroid synthesis and metabolism pathways in fish. J. Steroid Biochem. 92, 485-494. https://doi.org/10. 1016/j.jsbmb.2004.10.008.

Tovar, C C, 2019. Mercosur Regulation Lists Permitted Additives in Plastics for FCM [WWW Document]. Chemical Watch. URL. https://chemicalwatch.com/80722/ mercosur-regulation-lists-permitted-additives-in-plastics-for-fcms (accessed on March 5th 2020).

Trestrail, C, Walpitagama, M, Hedges, C, Truskewycz, A, Miranda, A, Wlodkowic, D, Shimeta, J, Nugegoda, D, 2020. Foaming at the mouth: ingestion of floral foam microplastics by aquatic animals. Sci. Total Environ. 705, 135826. https://doi.org/10 1016/j.scitotenv.2019.135826.

Turner, A, Holmes, L, 2011. Occurrence, distribution, and characteristics of beached plastic production pellets on the island of Malta (central Mediterranean). Mar. Pollut Bull. 62, 377-381. https://doi.org/10.1016/j.marpolbul.2010.09.027.

Turner, A, Holmes, L, Thompson, R C, Fisher, A S, 2020. Metals and marine microplastics: adsorption from the environment versus addition during manufacture, exemplified with lead. Water Res. 173, 115577. https://doi.org/10.1016/j.watres.2020.115577.

United Nations Environment Programme (UNEP), 2016. Marine Plastic Debris an Microplastics: Global Lessons and Research to Inspire Action and Guide Policy Change.
United States Environmental Protection Agency (USEPA), 2010. Hexabromocyclododecane (HBCD) Action Plan. Available at. https://www.epa.gov/ assessing-and-managing-chemicals-under-tsca/hexabromocyclododecane-hbcdaction-plan (accessed on March 29th 2020).

United States Environmental Protection Agency (USEPA), 2012. Polybrominated Diphenylethers (PBDEs) Significant New Use Rules (SNUR). Available at. https:// www.epa.gov/assessing-and-managing-chemicals-under-tsca/polybrominateddiphenylethers-pbdes-significant-new-use (accessed on March 29th, 2020).

Vandermeersch, G, Maria, H, Alvarez-muñoz, D, Cunha, S, 2015. Environmental contaminants of emerging concern in seafood - European database on contaminant levels Environmental contaminants of emerging concern in seafood - European database on contaminant levels. Environ. Res. 143, 29-45. doi:10.1016/ j.envres.2015.06.011.

Viarengo, A, Lowe, D, Bolognesi, C, Fabbri, E, Koehler, A, 2007. The use of biomarkers in biomonitoring: a 2-tier approach assessing the level of pollutant-induced stress syndrome in sentinel organisms. Comp. Biochem. Phys. C 146, 281-300. https://doi. org/10.1016/j.cbpc.2007.04.011.

Waldschläger, K, Lechthaler, S, Stauch, G, Schüttrumpf, H, 2020. The way of microplastic through the environment - application of the source-pathway-receptor model (review). Sci. Total. Environ. 713, 136584. https://doi.org/10.1016/j.scitotenv.2020. 136584.

Wang, J, Peng, J, Tan, Z, Gao, Y, Zhan, Z, Chen, Q, Cai, L, 2017. Microplastics in the surface sediments from the Beijiang River littoral zone: composition, abundance, surface textures and interaction with heavy metals. Chemosphere 171, 248-258. https: //doi.org/10.1016/j.chemosphere.2016.12.074.

Wang, X, Zhu, Q, Yan, X, Wang, Y, Liao, C, Jiang, G, 2020. A review of organophosphate flame retardants and plasticizers in the environment: analysis, occurrence and risk assessment. Sci.Total. Environ. 731, 139071. https://doi.org/10.1016/j.scitotenv. 2020.139071.

Wibe, ÅE, Billing, A, Rosenqvist, G, Jenssen, B M, 2002. Butyl benzyl phthalate affects shoaling behavior and bottom-dwelling behavior in three spine sticklebacks. Environ. Res. 89, 180-187. https://doi.org/10.1006/enrs.2002.4360.

Wurl, O, Lam, P K S, Obbard, J P, 2006. Occurrence and distribution of polybrominated diphenyl ethers (PBDEs) in the dissolved and suspended phases of the sea-surface microlayer and seawater in Hong Kong, China. Chemosphere 65, 1660-1666. https:// doi.org/10.1016/j.chemosphere.2006.02.024

Xie, Z, Ebinghaus, R, Temme, C, Lohmann, R, Caba, A, Ruck, W, 2007. Occurrence and air-sea exchange of phthalates in the arctic. Environ. Sci. Technol. 41, 4555-4560. https://doi.org/10.1021/es0630240.

Xue, B, Zhang, L, Li, R, Wang, Y, Guo, J, Yu, K, Wang, S, 2020. Underestimated microplastic pollution derived from fishery activities and "Hidden" in deep sediment. Environ. Sci. Technol. 54, 2210-2217. https://doi.org/10.1021/acs.est.9b04850.

Yamamoto, T, Yasuhara, A, 1999. Quantities of bisphenol a leached from plastic waste samples. Chemosphere 38, 2569-2576. https://doi.org/10.1016/S00456535(98)00464-0.

Zhang, H, Zhou, Q, Xie, Z, Zhou, Y, Tu, C, Fu, C, Mi, W, Ebinghaus, R, Christie, P, Luo, $\mathrm{Y}, 2018$. Occurrences of organophosphorus esters and phthalates in the microplastics from the coastal beaches in north China. Sci. Total. Environ. 616-617, 1505-1512. https://doi.org/10.1016/j.scitotenv.2017.10.163. 